\title{
Interaction of soil-inorganic nitrogen in rice fields of Kilombero Floodplain, Tanzania
}

\author{
AUSTIANO BERNARD YOBELE, METHOD KILASARA ${ }^{\boldsymbol{}}$ \\ Sokoine University of Agriculture. P.O. Box 3000, Chuo Kikuu, Morogoro, Tanzania. Tel. + 255-23-2603511-4, `email: mmkilasara@ yahoo.com
}

Manuscript received: 3 January 2021. Revision accepted: 13 April 2021.

\begin{abstract}
Yobele AB, Kilasara M. 2021. Interaction of soil-inorganic nitrogen in rice fields of Kilombero Floodplain, Tanzania. Intl J Bonorowo Wetlands 11: 32-47. At Ifakara Morogoro Region, a study was done to determine the effect of selected crop management interventions and hydrological conditions on soil $\mathrm{NH}_{4}{ }^{+}$and $\mathrm{NO}_{3}{ }^{-}$concentration. The study chose Valley Middle and Fringe locations as distinct hydrological zones. Three repetitions of an experiment with six treatments were laid down: semi-natural vegetation (TR1), farmers practice (TR2), bunding alone (TR3), bunding + $60 \mathrm{kgN} / \mathrm{ha}$ (TR4), bunding $+120 \mathrm{kgN} / \mathrm{ha}$ (TR5), and bunding+Lablab green manure (TR6). As a test crop, the SARO 5 rice variety was employed. The trials took place during the pre-season of 2014/15 and the regular 2015/16. Data were gathered from a depth of 0-10 cm in the soil. Using the GenStat Program, two-way ANOVA and post hocTukey HD test statistical analyses were done. Pre-season $\mathrm{NH}_{4}{ }^{+}$concentrations followed three distinct patterns: an initial increase to peak levels within 3 and 6 weeks for the Fringe and Middle sites, a fall ( $7^{\text {th }}$ to $9^{\text {th }}$ week for the Middle, and $4^{\text {th }}$ to $6^{\text {th }}$ week for the Fringe), and an increase (from $7^{\text {th }}$, Fringe and $10^{\text {th }}$ week, Middle). The Middle site had the highest peak $\mathrm{NH}_{4}{ }^{+}$levels (TR6-0.007401, TR5-0.004776, and TR4-0.04525, g/kg soil, and TR4-0.004524, TR5-0.004595, g/kg soil, respectively). At the Middle and Fringe locations, peak NH $4^{+}$ values varied considerably between treatments, following the trend TR6>TR5>TR3>TR4>TR1 $>$ TR2 and TR4>R6=TR5=TR3+TR2 $>$ TR1. Nitrate levels declined within 1-2 weeks at both sites, reaching their lowest levels between 4 and 7 weeks, and then gradually increased to 10. Rice cropping season $\mathrm{NH}_{4}{ }^{+}$and $\mathrm{NO}_{3}{ }^{-}$variation followed a similar pattern for both locations, except a sharp increase in treatments with $\mathrm{N}$ input during weeks 8 and 10. Hydrological conditions had no significant effect on the $\mathrm{NH}_{4}{ }^{+}$and $\mathrm{NO}_{3}{ }^{-}$levels $(\mathrm{P}=0.05)$. The study advises that the experiment be repeated under controlled conditions.
\end{abstract}

Keywords: Crop management, hydrology, inorganic nitrogen, Kilombero Floodplain, rice fields

\section{INTRODUCTION}

Rice is a commercial crop whose productivity improves in the Kilombero Valley (Kato 2007). Mineral nitrogen fertilizer is becoming an increasingly important input in crop productivity, particularly in irrigated systems (Nascente et al., 2009). The mineral nitrogen in the soil is quite volatile (Becker et al., 2007). The processes that determine the dynamic nature of mineral $\mathrm{N}$ are highly dependent on a variety of soil conditions, the most critical of which is soil hydrological conditions (Reddy and De Laune 2008; Suryantini 2016; Njoroge et al. 2018), soil pH (Mokata and Takalapeta 2021), $\mathrm{N}$ input (Yeasmin et al 2012), and crop husbandry (Lou et al. 2011; Susanto et al. 2018). The type of nitrogen applied and the rate at which it is used determine its usefulness for crop yield in wetland environments (Ngwene et al., 2013).

It is typical to compensate for mineral $\mathrm{N}$ deficit in wetland soils by boosting the organic or inorganic mineral $\mathrm{N}$ pool (endogenous and exogenous $\mathrm{N}$ sources), hence contributing to production increases (Yeasmin et al., 2012). Most plants acquire nitrogen in $\mathrm{NO}_{3}^{-}$(Buresh et al. 2008). Rice is unique among plants in that it can absorb nitrogen in the $\mathrm{NH}_{4}{ }^{+}$state (Wang et al. 1993). Additionally, both $\mathrm{NH}_{4}{ }^{+}$and $\mathrm{NO}_{3}{ }^{-}$are highly active compounds highly dependent on the wetland hydrology, namely the amount of free water and redox potential (Pezeshki and Delaune
2012). As a result, the condition of $\mathrm{NH}_{4}{ }^{+}$and $\mathrm{NO}_{3}{ }^{-}$in wetlands and their dynamics are critical for $\mathrm{N}$ management and paddy production (Buresh et al., 2008). In paddy rice production systems, $\mathrm{N}$ can be lost by a variety of mechanisms, including leaching (Kimetu et al. 2006), volatilization (Loomis and Connor 1992; Jones et al. 2007), denitrification (Brady and Weil 1999), and nitrification (Sahrawat 2010). Apart from resulting in net nitrogen loss, these processes contribute to detrimental environmental consequences and climate change (Reddy and DeLaune 2008). For example, it is well established that $\mathrm{NH}_{4}{ }^{+} \mathrm{N}$ is harmful to aquatic life even at low concentrations in water (Reddy and DeLaune 2010). On the other side, $\mathrm{NH}_{4}{ }^{+}$ volatilization increases the likelihood of adverse effects of climate change (Audet et al., 2014). Under aerobic circumstances, $\mathrm{NH}_{4}^{+}$, a byproduct of mineralization, is easily oxidized to $\mathrm{NO}_{3}^{-}$. The latter travels downward from the oxidized zone into the anaerobic area, where it is converted to $\mathrm{NO}_{2}$ and subsequently to $\mathrm{N}_{2} \mathrm{O}$ and $\mathrm{N}_{2}$ (Smil 2000).

Both contribute directly to global warming by degrading the ozone layer (Audet et al., 2014). Similarly, when $\mathrm{NO}_{3}{ }^{-} \mathrm{N}$ is leached from flooded soils, it raises the danger of groundwater pollution (Yeasmin et al., 2012). Therefore, it is vital to monitor the inorganic $\mathrm{N}$ status in wetland rice production for economic reasons, environmental protection for the well-being of wetland biodiversity, and minimize the impact of added $\mathrm{N}$ 
fertilizers on greenhouse gas emissions. Numerous variables affect the dynamics of mineral or inorganic $\mathrm{N}$ in wetlands. These include temperature (Wang et al. 2004), redox potential (Pezeshki and Delaune 2012), moisture regime (Wang et al. 2004; Reddy and DeLaune 2008), C: N ratio (Smith 2010), microbial activity, and biomass (Reddy and DeLaune 2008), electron acceptor availability (Sugihara et al. 2010 a,b). Paddy's nitrogen needs fluctuate according to crop growth or development (Muhammad et al., 2010).

It is crucial to understand the amount of mineral $\mathrm{N}$ present throughout the growing season under selected agricultural practices used by small-scale farmers in floodplains, particularly in the Kilombero valley, because no research on the mineral $\mathrm{N}$ dynamics in wetlands soils with adequate regard for hydrological conditions have been done so far. Studies According to Corstanje and Reddy (2004), soil drying after paddy production increases mineral $\mathrm{N}$ in the soil. Because the level of this nutrient is fluctuating, it has ramifications for both water quality and greenhouse gas emissions during the subsequent flooding period (Yeasmin et al., 2012). Therefore, it is critical to determine the mineral $\mathrm{N}$ content before the rainy season or the beginning of the following rice crop in a wetland. In the Kilombero flood plain, where information is scarce, a good understanding of the difficulties outlined above will permit economic and sustainable rice farming.

The objective of this study was: (i) To see how different crop management interventions affect the fluctuation of $\mathrm{NH}_{4}{ }^{+}$and $\mathrm{NO}_{3}{ }^{-}$content before and after rice transplanting. (ii) To determine the impact of hydrological conditions on the levels of $\mathrm{NH}_{4}{ }^{+}$and $\mathrm{NO}_{3}{ }^{-}$during the paddy growth season.

\section{MATERIALS AND METHODS}

\section{Study sites}

This research was carried out at the Kilombero Valley Floodplain Wetland, located in the Kilombero area of Morogoro (Figure 1). It has a total area of $7967 \mathrm{~km}^{2}$ (Samora et al., 2013). The climate in the Valley is subhumid tropical, with relative humidity ranging from 70 to $80 \%$ and annual rainfall ranging from 1200 to $1400 \mathrm{~mm}$ (MNRT 2004a). There are two rainy seasons in the Valley: a short rainy season known as Vuli that lasts from December to February and a long rainy season known as Masika that lasts from March to May/June. The temperature in the atmosphere varies between $20^{\circ} \mathrm{C}$ and $30^{\circ} \mathrm{C}$ (MNRT 2004b).

The flood plain is defined by fertile swelling shrinking soils inundated primarily throughout the long rainy season but develop cracks during the dry season, particularly between July and October (Samora et al., 2013). Agriculture, cattle husbandry, fishing, and business are the primary activities in the area (Kato 2007).

\section{Site description of the study sites}

Three experimental sites were established in three villages chosen for their distinct soil hydrological characteristics. These were Kantindiuka, Kiyongwire, and Kivukoni Villages, classified as Fringe, Middle, and Central zones, respectively, in terms of river flooding (Figure 1). These represent the study's three distinct hydrological conditions.

Thus, the locations' corresponding qualities are discussed. (i) The Center zone denotes the wetland's primary water flow center. It is defined by persistent circumstances of water saturation with a peak water flood height of $1 \mathrm{~m}$ and a flooding period of around 2-3 months during which water covers the ground surface. (ii) The Middle site is a transition zone between the floodplain's protracted inundated center zone and its least flooded portion (Fringe). It is defined by a flooding period of less than a month during which flowing water completely covers the land surface but leaves the root zone moist throughout the cropping season and is underlain by a saturated soil layer. (iii) The Fringe zone is saturated with water to the ground surface for less than two months. It has a significantly longer surface water saturation than the Middle site due to seepage water from the hills following rain that lasts longer than the major river flooding in the former. Therefore, the site located in the Center, Middle, and Fringe portions of the Kilombero River flood plain will be referred to throughout the paper as the Centre, Middle, and Fringe zone or site.

\section{Experimental design}

During the 2014/5 and July 2015/6 rain seasons, an experiment with six treatments duplicated three times in a completely randomized block design (CRBD) was conducted at three sites with varying hydrological conditions. The treatments included the following: (i) seminatural vegetation that was previously planted but left without crop (TR1) (ii) Farmers' practices - rice crop grown without the addition of mineral $\mathrm{N}$ and the use of bunds (TR2). (iii) Rice crop + bunds but without mineral $\mathrm{N}$ application (TR3). (iv) Rice crop + Bunds $+60 \mathrm{~kg} / \mathrm{hectare}$ of Urea (TR4). (v) Rice crop plus Bunds $+120 \mathrm{~kg} / \mathrm{hectare}$ of urea (TR5). (vi) Rice + bunds + laboratory green manure devoid of mineral nitrogen (TR6). The former was put into the soil 45 days after germination in the lablab treatment. The amount absorbed into the soil was equal to $50 \mathrm{~kg} / \mathrm{ha}$ of N.

In this study, the paddy (Oryza sativa) variety TXD 306, popularly known as SARO 5", was employed as a test crop. The experiment was conducted on $5 \times 6 \mathrm{~m}^{2}$ plots with $20 \times 20 \mathrm{~cm}^{2}$ plant spacing, as Kanyeka et al. (2007) advised. Throughout the cropping season, standard agronomic crop management practices were followed.

\section{Determination of hydrological-based characteristics Rainfall of the studied sites}

An automatic weather station collected rainfall data at the study locations. Hourly measurements were taken and stored in a data logger. The distribution of rainfall for the 2015/16 cropping season is shown in Figure 2. 

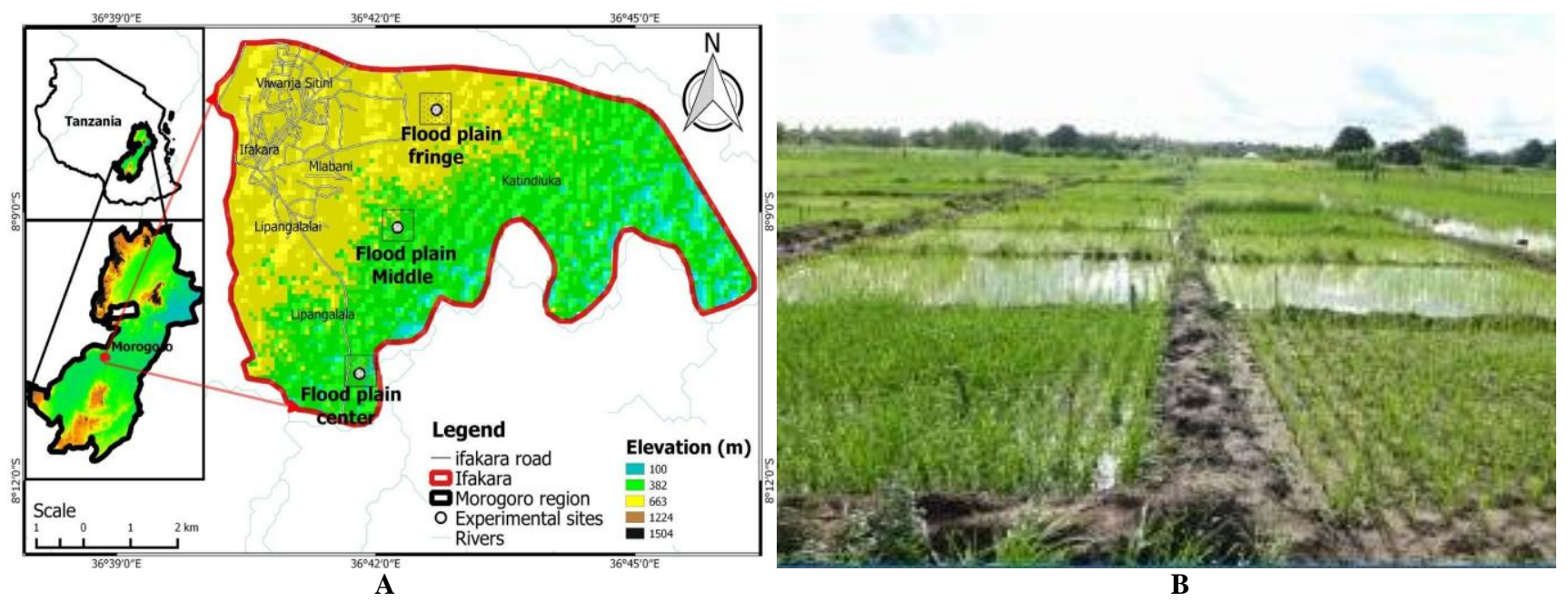

Figure 1. A. Location map of the experimental sites in rice fields of Kilombero Floodplain, Tanzania. B. Fringe experimental site four weeks after paddy rice transplantation

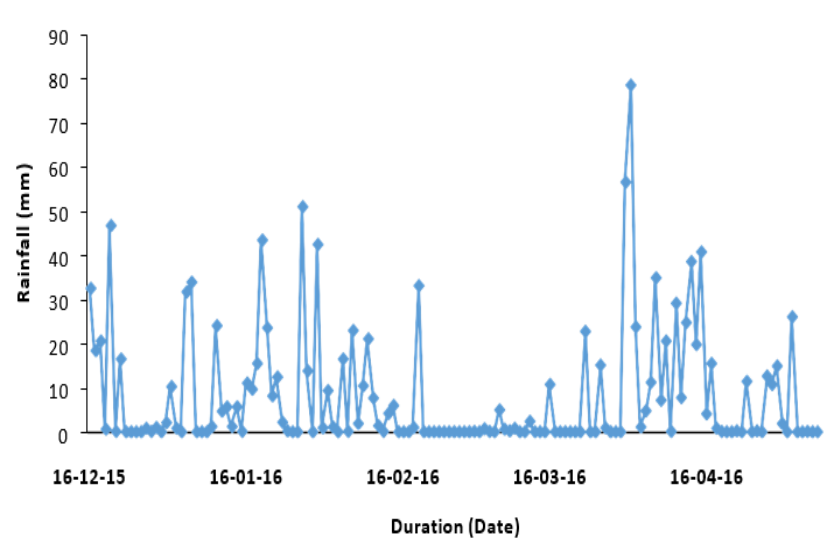

Figure 2. The rainfall during the $2015 / 16$ rainy season

\section{Soil moisture measurements}

Virrib sensors were used to collect data on soil moisture. A Virrib sensor was mounted horizontally at a depth of $10 \mathrm{~cm}$ from each experimental site, with automatic measurements taking place every 15 minutes (Walker et al., 2004).

\section{Redox potential measurement}

The redox levels at each site were determined using the method established by Vorenhout et al. (2004). Daily values were recorded continuously using an $\mathrm{Ag} / \mathrm{AgCl}$ electrode. A mobile PC was used to configure the system and collect data. A central PIC processor (PIC16F877) processed the data and stored it in a 256 Kbit ferroelectric non-volatile random-access memory (FRAM) serial memory. The data logger was configured and collected using the Hypnos Data Collector Version 1.4, written using LabView.

\section{Determination of the soil characteristics}

For laboratory characterization, soil samples were collected from the experimental sites. First, 18 soil samples were randomly obtained from the $0-30 \mathrm{~cm}$ depth at each experimental site and combined to form a composite sample. Next, composite soil samples were packed and transferred to the laboratory, where they were air-dried, crushed, and sieved using a $2 \mathrm{~mm}$ sieve.

\section{Soil $\mathrm{NH}_{4}{ }^{+}$and $\mathrm{NO}_{3}{ }^{-}$content data collection}

The following data were collected from the experimental plots: $\mathrm{NH}_{4}{ }^{+}$and $\mathrm{NO}_{3}{ }^{-}$concentrations. Before data collection, soil samples from each subject were obtained and prepared in the manner described below.

\section{Soil sampling and sample preparation}

During the 2015/16 rain season, soil samples for $\mathrm{NH}_{4}{ }^{+}$ and $\mathrm{NO}_{3}^{-}$analysis were obtained from individual plots. Before and during the farming season, samples were taken. The pre-paddy growing season (dry-wet transition period) lasted from 16 December (the start of the 2015/16 short rainy season) to 4 March 2016, with weekly samples collected. The second data gathering season ran from 18 March until 8 July 2016. Every two weeks, soil samples were taken. Soil samples were taken randomly from each plot using a soil auger at depths ranging from $0-10 \mathrm{~cm}$. Six soil samples from each treatment were combined thoroughly to create a composite sample.

Individual samples were then sealed in labeled plastic bags, placed in a cooling box filled with ice, and sent immediately to the laboratory for analysis. The samples were immediately frozen in the laboratory before extraction and subsequent $\mathrm{NH} 4+$ and NO3-analysis. Of the three study sites, sampling at the Valley Centre site was halted due to flooding shortly after the short rain season. 


\section{Data analysis}

\section{Soil characterization}

The soil samples determined particle size distribution, bulk density, porosity, particle density, $\mathrm{pH}$, total $\mathrm{n}$, total carbon, and plant-available phosphorus. The hydrometer method was used to determine the particle size distribution of soil samples spread in sodium hexametaphosphate solution at 5\% (Gee and Bauder 1986). Bulk Density was calculated using the procedure described by Blake and Hartage (1986). The particle was determined using the pycnometer method, which Blake and Hartage invented (1986). Porosity was estimated using the formula (1$\mathrm{BD} / \mathrm{PD}$, where $\mathrm{BD}=$ bulk density and $\mathrm{PD}=$ Particle density).

The amount of organic carbon in the air was assessed using the Walkey-Black wet combustion method (Nelson and Sommers 1982). According to Bremner and Mulvaney's methodology, total nitrogen was determined using the micro-Kjeldahl method (1982). Olsen and Sommers (1982) described the approach was used to determine the available phosphorus. Finally, $\mathrm{pH}$ was determined using a soil: water suspension (1:2:5) following Mc Lean's procedure (1982).

\section{Determination of $\mathrm{NH}_{4}{ }^{+}$and $\mathrm{NO}_{3}{ }^{-}$}

Before $\mathrm{NH}_{4}{ }^{+}$and $\mathrm{NO}_{3}{ }^{-}$extraction, frozen samples were defrosted. Each analyzed plot's moisture content was determined using a different soil sample. To a consistent weight, these samples were defrosted and weighed before and after oven drying at $105^{\circ} \mathrm{C}$. Considering an analytical balance was used to determine the dry weight. After defrosting, around 20 to $25 \mathrm{~g}$ of soil samples were weighed and immediately placed in the oven. The moisture content was expressed as a fraction of the sample's oven-dry weight. This was converted from the field weight to the oven-dry weight equivalent.

Fifteen grams equivalent of wet soil was shaken with 90 $\mathrm{ml}$ of $0.01 \mathrm{M} \mathrm{CaCl}_{2}$ for 60 minutes at $189 \mathrm{rpm}$ (Houba et al. 1986), filtered, and treated with one drop of $0.01 \mathrm{M}$ sulfuric acid to prevent microbial development before being used to determine the concentrations of $\mathrm{NH}_{4}{ }^{+}$and $\mathrm{NO}_{3}{ }^{-}$(Nascente et al. 2009). The $\mathrm{NH}_{4}{ }^{+}$concentration in the soil extract was determined using the method established by Reardon et al. (1966). $0.01 \mathrm{M} \mathrm{NaOH}$ was used to alter the $\mathrm{pH}$ of a $20 \mathrm{ml}$ portion of the extract to 7. (Kunamneni et al., 2003). A $0.1 \mathrm{ml}$ aliquot of the neutral ( $\mathrm{pH} \mathrm{7)}$ extract was pipetted into $16 \mathrm{~mm}$ cells and incubated for 20 minutes with a mixture of ammonia, salicylate, and cyanurate F5 powders. The $\mathrm{NH}_{4}{ }^{+}$content was determined calorimetrically at a wavelength of $690 \mathrm{~nm}$ using a photo flex photometer. $\mathrm{NO}_{3}{ }^{-}$was determined using Swinehart and Warren's technique (1953). Next, $1 \mathrm{~mL}$ of the soil extract obtained in the previous preparation was pipetted into 16 $\mathrm{mm}$ cuvette cells and incubated for 10 minutes with Vario nitrate Chromotropic powder. The $\mathrm{NO}_{3}{ }^{-}$the content of the extract was measured using spectrophotometry at a wavelength of $436 \mathrm{~nm}$. Both $\mathrm{NH}_{4}{ }^{+}$and $\mathrm{NO}_{3}{ }^{-}$concentrations were expressed in $\mathrm{g} / \mathrm{kg}$ soil.

\section{Statistical analysis}

GenStat Computer Software was used to conduct a post hoc Tukey HD test and two-way ANOVA analysis (Payne 2009). To compare the mean values of $\mathrm{NH}_{4}{ }^{+}$and $\mathrm{NO}_{3}{ }^{-}$ contents between treatments, the post hoc Tukey HD test was performed. In addition, the influence of the hydrological zone between the Middle and Fringe sites on $\mathrm{NH}_{4}{ }^{+}$and $\mathrm{NO}_{3}{ }^{-}$concentration was investigated using a twoway ANOVA.

\section{RESULTS AND DISCUSSION}

\section{Characteristics of the studied soils}

Tables 1 and 2 summarize the physical and chemical characteristics of the soils tested. The soil textures of the investigated soils vary considerably. Clay concentration reduced as the distance from the river source increased. The Centre site has approximately $60 \%$ clay, while the Fringe site contains the least clay $(30 \%)$. All sites had a high silt concentration, ranging from $26 \%$ in the Centre and Middle sites to $39 \%$ in the Fringe site. The porosity of the soil was $54 \%$ in the Center, $48 \%$ in the Middle, and $54 \%$ in the Fringe, respectively. The $\mathrm{C} / \mathrm{N}$ ratio was $11.8 \%$ in the center, $12.4 \%$ in the middle, and $16.5 \%$ in the fringe. The ratio increased as the hydrological conditions deteriorated from the Center to the Fringe.

Table 1. Soils physical characteristics of the studied sites

\begin{tabular}{lcccccc}
\hline \multirow{2}{*}{ Site name } & Sand (\%) & Silt (\%) & Clay (\%) & BD $\left(\mathbf{M g ~ m}^{-\mathbf{3}}\right)$ & PD $\left(\mathbf{M g ~ m}^{\mathbf{- 3}}\right)$ & Porosity $(\boldsymbol{\%})$ \\
\cline { 2 - 7 } & 29.61 & 39.61 & 30.78 & 1.22 & 2.66 & 54 \\
Fringe & 40.34 & 26.87 & 32.44 & 1.34 & 2.66 & 49 \\
Middle & 12.00 & 26.54 & 61.47 & 1.21 & 2.66 & 54 \\
Center & &
\end{tabular}

Table 2. Soils chemical characteristics of the studied sites

\begin{tabular}{lccccc}
\hline \multicolumn{1}{c}{ Site name } & \multicolumn{5}{c}{ Chemical properties } \\
\hline Fringe & Organic C $\mathbf{( \% )}$ & Total $\mathbf{~}(\boldsymbol{\%})$ & $\mathbf{C} / \mathbf{N}$ & Extractable P $\left(\mathbf{m g ~ k g}^{\mathbf{- 1}}\right)$ & $\mathbf{p H}$ \\
Middle & 1.82 & 0.11 & 16.5 & 49.98 & 6.1 \\
Center & 0.87 & 0.07 & 12.4 & 16.52 & 5.8 \\
\hline
\end{tabular}


With a $\mathrm{pH}$ of 4.9 , the Center was the most acidic. The soil $\mathrm{pH}$ climbed steadily from the Centre to the Fringe site, reaching 5.8 and 6.1 in the Middle and Fringe locations, respectively. All sites have a relatively low organic carbon content. It was approximately $1.8 \%$ at the Centre and Fringe locations, but only $0.8 \%$ at the Middle location. The total nitrogen level was comparable in the Centre and Fringe sites $(0.16$ and $0.11 \%)$ but was relatively low at the Middle site $(0.07 \%)$. At the Center, Middle, and Fringe, the equivalent $\mathrm{C}$ : $\mathrm{N}$ ratios were 11.7, 12.4, and 16.5, respectively.

\section{Variation of soil moisture in the root zone of the studied} soils during the pre-paddy growing season

The soil's moisture level between 0 and $10 \mathrm{~cm}$ changed throughout the season, as indicated in Table 3 . It varied between 12.3 and $31.6 \%$ at the Middle site and 16.2 to $46.4 \%$ at the Fringe location. Between the two sites, the pattern of moisture content fluctuation was distinct.

During the first four weeks, the Middle site was significantly drier than the Fringe zone, with moisture content varying between 12 and $22 \%$, compared between 41 and $46 \%$. It was noteworthy that soon following the first rains in early December, the Fringe zone became wetter due to surface water flow from surrounding mountain slopes. At the Middle location, this phenomenon did not occur. Due to the inadequacy of the data for assessing the extent of soil aeration, a phenomenon associated with redox processes in the soil (Lin and Doran 1984), the data were converted to a percentage of water-filled pore spaces to interpret their relationship with the redox-related characteristics of the studied soils.

As illustrated in Table 4, the percentage of WFP varied significantly within and between the two sites. It varied between 22.7 and $53.9 \%$ at the Middle site for nine out of ten weeks of the trial period and peaked at $64.3 \%$ at week twenty. It fluctuated between soils at the Fringe site over the first four weeks, ranging from 76.5 to $86.0 \%$ WFP. During weeks 4 and 7, the WFP percentage varied between 27.4 and $31.1 \%$. This was the site's dry phase. Between weeks 9 and 10, the percentage of WFP began to grow again (55.0 to $56.8 \%$ ). These are later described in detail concerning the change in $\mathrm{NH}_{4}{ }^{+}$and $\mathrm{NO}_{3}{ }^{-}$concentrations at these sites.

\section{Variation of the redox potential in the root zone of the studied soils \\ Variation of redox potential at the Middle and Fringe sites during the pre-paddy cropping season}

The Middle site's redox potential values fluctuated significantly during the changeover period. They were between +341.5 and $+394.7 \mathrm{mV}$. A comparable situation existed between weeks 0 and 7 at the Fringe location. From week 7 to week 10, elevated Eh values (more than +600 $\mathrm{mV}$ ) were seen. The potential redox values within the root zone for both the Middle and Fringe locations during the primary cropping season are shown in Table 5. Again, there were significant differences between the two sites. Eh varied between +121.6 and $+394.2 \mathrm{mV}$ at the Middle site.

Variation of redox potential at the Middle and Fringe sites during the paddy cropping season

The lowest readings ( 121.6 to $237.0 \mathrm{mV}$ ) were obtained during the first 3 weeks, while between 348.1 and 478.0 $\mathrm{mV}$ were obtained between weeks 6 through 16. At the Fringe location, a similar tendency was seen, though with some variance. By and large, the soils investigated at the Middle and Fringe locations had greater redox levels toward the end of the cropping season (Table 6). For example, this began at the Middle site during week 6, but it started at the Fringe location.

Table 3. Variation of soil moisture content in the root zone $(0-10 \mathrm{~cm})$ in the studied soils during the pre-paddy growing season

\begin{tabular}{lccccccccccc}
\hline \multirow{2}{*}{ Site } & \multicolumn{10}{c}{ Soil moisture content (\%) } \\
\cline { 2 - 12 } & Week 0 & Week 1 & Week 2 & Week 3 & Week 4 & Week 5 & Week 6 & Week 7 & Week 8 & Week 9 & Week 10 \\
\hline Middle & 15.1 & 12.3 & 13.1 & 22.7 & 26.4 & 24.2 & 17.5 & 17.7 & 19.5 & 14.4 & 31.6 \\
Fringe & 43.4 & 46.4 & 43.1 & 41.3 & 16.2 & 14.9 & 16.8 & 14.7 & 22.7 & 29.7 & 30.6 \\
\hline
\end{tabular}

Table 4. Water-filled pore space at the Middle and Fringe sites during the pre-paddy growing season

\begin{tabular}{|c|c|c|c|c|c|c|c|c|c|c|c|}
\hline \multirow{2}{*}{ Site } & \multicolumn{11}{|c|}{ Percentage water-filled pore space (\% WFP) } \\
\hline & Week0 & Week1 & Week2 & Week3 & Week4 & Week5 & Week6 & Week7 & Week8 & Week9 & Week10 \\
\hline Middle & 30.8 & 25.1 & 26.7 & 46.4 & 53.9 & 49.4 & 35.7 & 36.2 & 39.9 & 29.5 & 64.6 \\
\hline Fringe & 80.5 & 86.0 & 79.8 & 76.5 & 30.0 & 27.7 & 31.1 & 27.4 & 42.1 & 55.05 & 56.8 \\
\hline
\end{tabular}

Table 5. Variation of Redox potential (eh) at the Middle and Fringe sites during the pre-paddy cropping season

\begin{tabular}{lccccccccccc}
\hline \multirow{2}{*}{ Site } & \multicolumn{10}{c}{ Redox potential (mV) } \\
\cline { 2 - 13 } & Week 0 & Week 1 & Week 2 & Week 3 & Week 4 & Week 5 & Week 6 & Week 7 & Week 8 & Week 9 & Week 10 \\
\hline Middle & 392 & 383.7 & 341.3 & 344.5 & 349.3 & 350.9 & 361.9 & 365.6 & 363.6 & 371.8 & 394.7 \\
Fringe & 358.7 & 349.6 & 345.3 & 351.1 & 348.1 & 341.6 & 346.2 & 350.3 & 672.7 & 676.7 & 688.9 \\
\hline
\end{tabular}


Table 6. Variation of redox potential at the Middle and Fringe sites during the paddy-cropping season

\begin{tabular}{lccccccccc}
\hline \multirow{2}{*}{ Site } & \multicolumn{8}{c}{ Redox potential $(\mathbf{m V})$} \\
\cline { 2 - 11 } & Week 0 & Week 2 & Week 4 & Week 6 & Week 8 & Week 10 & Week 12 & Week 14 & Week 16 \\
\hline Middle & 237.0 & 204.8 & 121.6 & 348.3 & 394.2 & 347.3 & 478.0 & 349.0 & 349.4 \\
Fringe & 195.3 & 209.2 & 352.3 & 242.9 & 403.7 & 295.5 & 408.3 & 350.2 & 357.5 \\
\hline
\end{tabular}

\section{Effect of crop management interventions on the variation of $\mathrm{NH}_{4}^{+}$content}

The data illustrating the fluctuation in the $\mathrm{NH}_{4}{ }^{+}$ concentration of the examined soils are divided into two seasons: the dry-wet transitional (pre-paddy growing season) and the paddy cropping season.

\section{$\mathrm{NH}_{4}{ }^{+}$variability during the pre-paddy growing season}

The data presented below consists of 2 sites: The Middle and the Fringe sites.

\section{$\mathrm{NH}_{4}{ }^{+}$content at the Middle site}

The results indicated a range of $\mathrm{NH}_{4}{ }^{+}$concentrations and a four-stage process. The initial $\mathrm{NH}_{4}{ }^{+}$content at the start of the rainy season, the subsequent increase in $\mathrm{NH}_{4}{ }^{+}$to a peak value, the subsequent fall in $\mathrm{NH}_{4}{ }^{+}$content to $0 \mathrm{~g} / \mathrm{kg}$ soil, and finally, the following increase $\mathrm{NH}_{4}{ }^{+}$content (Figure 3). At week 0, the Middle site's $\mathrm{NH}_{4}{ }^{+}$content was greatest in TR6 $(0.00215 \mathrm{~g} / \mathrm{kg}$ soil $)$ and lowest in TR2 and TR5 (0.000698 and $0.000958 \mathrm{~g} / \mathrm{kg}$ soil, respectively). At ( $\mathrm{P}$ $=0.05)$, these values were statistically different (Table 7). The remainder of the treatments had intermediate values.

From week $0, \mathrm{NH}_{4}{ }^{+}$grew gradually to reach a peak value between weeks 4 and 6 (Figure 4). The peak readings for $\mathrm{NH}_{4}{ }^{+}$were as follows: TR6>TR5>TR3>TR4>TR1>TR2. Between weeks 4 and 6 , depending on the treatment, $\mathrm{NH}_{4}{ }^{+}$ levels gradually decreased to their lowest levels at week 9 before increasing progressively at week 10 (Figure 4). At week 10 , this increase reached considerably different values (Table 7), with TR3 reaching the most significant value.

At week 6, significant differences in $\mathrm{NH}_{4}{ }^{+}$content were observed between treatments, which can be classified into four categories: TR6 had the highest $\mathrm{NH}_{4}{ }^{+}$content $(0.00720 \mathrm{~g} / \mathrm{kg}$ soil $)$, followed by TR4 and TR5 $(0.004525$ and $0.004325 \mathrm{~g} / \mathrm{kg}$ soil, respectively), and TR3 (0.002058 $\mathrm{g} / \mathrm{kg}$ soil). In contrast, TR2 and TR1 had the lowest $\mathrm{NH}_{4}{ }^{+}$ content $(0.000514$ and $0.00020 \mathrm{~g} / \mathrm{kg}$ soil, respectively). These categories were statistically distinct (Table 7). Between weeks 9 and 10, practically all treatments experienced a significant increase in $\mathrm{NH}_{4}{ }^{+}$. At week 10, TR 5 and TR3 had the most critical and lowest $\mathrm{NH}_{4}{ }^{+}$contents (0.005478 and $0.004212 \mathrm{~g} / \mathrm{kg}$ soil, respectively).

\section{$\mathrm{NH}_{4}{ }^{+}$content at the Fringe site}

The fluctuation in $\mathrm{NH}_{4}{ }^{+}$concentrations at the Fringe site changed throughout time, as illustrated in Figure 4. On the first day following the initial rainstorm, the $\mathrm{NH}_{4}{ }^{+}$ content differed significantly between treatments. TR2, TR3, TR4, and TR5 treatments included considerably more $\mathrm{NH}_{4}{ }^{+}$(above $0.003 \mathrm{~g} / \mathrm{kg}$ soil) than TR1 and TR6 treatments contained (0.001 and $0.002 \mathrm{~g} / \mathrm{kg}$ soil, respectively) (Table
8). $\mathrm{NH}_{4}{ }^{+}$content varied significantly across all treatments throughout the pre-paddy growing season. Regardless of the imposed management intervention, the $\mathrm{NH}_{4}{ }^{+}$content changed predictably, demonstrating three separate periods. These were: an initial period that corresponded to the start of the rains, during which the $\mathrm{NH}_{4}{ }^{+}$content was relatively high and showed a tendency to increase to a peak value, followed by a second period during which the $\mathrm{NH}_{4}{ }^{+}$content decreased over time to zero, and finally a period of $\mathrm{NH}_{4}^{+}$ increase over time (Figure 4).

During the initial phase of $\mathrm{NH}_{4}{ }^{+}$growth, discrepancies in the peak value and the time necessary to reach it existed. For example, in TR4 (60 kg N + bunds), $\mathrm{NH}_{4}{ }^{+}$nearly quadrupled in a week (0.003 to $0.005 \mathrm{~g} / \mathrm{kg}$ soil). TR6 (Green manure + bunds) had a similar trend, increasing from $0.01 \mathrm{~g} / \mathrm{kg}$ soil in week 0 to $0.004 \mathrm{~g} / \mathrm{kg}$ soil in week 3 (Table 8). The subsequent treatments increased $\mathrm{NH}_{4}{ }^{+}$less effectively and differed in the time required to attain peak $\mathrm{NH}_{4}{ }^{+}$content. TR3, TR4, and TR5 reached their highest $\mathrm{NH}_{4}{ }^{+}$values in week 1, TR1 and TR2 in week 2, and TR6 in week 3 .

The reduction pattern in $\mathrm{NH}_{4}{ }^{+}$from the peak to the lowest value varied significantly between treatments, as illustrated in Figure 4. The reduction began in week one for TR2, TR3, TR4, and TR5; week two for TR2, and week three for TR6. The lowest or absolute 0 results were obtained at various times: week 4 for TR4 and TR5, and week 5 for the remaining treatments.

The period during which no $\mathrm{NH}_{4}{ }^{+}$was detected varied according to treatment: 4 weeks (weeks 4-7) for TR4 and TR5; 3 weeks (weeks 5-7) for TR2 and TR3 (weeks 5-7); and 2 weeks (weeks 5-6) for TR1 and TR6, respectively.

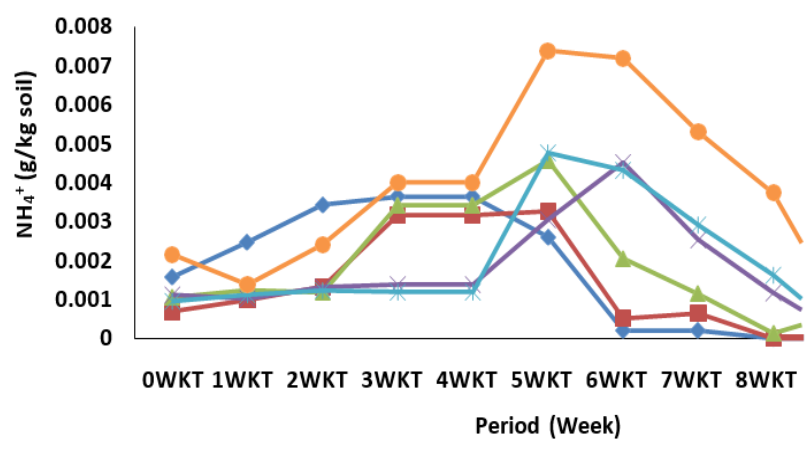

Figure 3. Pre-rice growing season $\mathrm{NH}_{4}{ }^{+}$variation at the Middle site. WKT: Week before Transplanting Rice (Dry -wet transition weeks) 


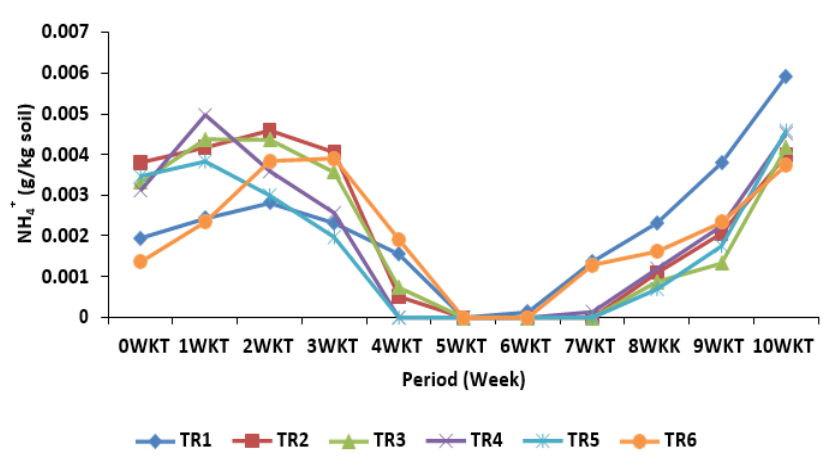

Figure 4. $\mathrm{NH}_{4}{ }^{+}$content during the pre-paddy growing season at the Fringe site. WKT: Week before transplanting rice (dry-wet transition weeks)

Additionally, the increase in $\mathrm{NH}_{4}{ }^{+}$throughout the final period varied amongst regimens. At week 10, the biggest increase $(0.006 \mathrm{~g} / \mathrm{kg}$ soil) was reported in TR 1 , whereas the smallest $(0.003 \mathrm{~g} / \mathrm{kg}$ soil) was observed in TR6. At week 10 , the difference between treatments was statistically significant $(\mathrm{P}=0.05)$ (Table 8$)$.

The duration of mineralization required to reach maximal $\mathrm{NH}_{4}{ }^{+}$was as follows: RT4>TR6=TR5=TR3=TR2 $>$TR1 These findings indicate that the lablab green manure treatment was the most effective at increasing peak $\mathrm{NH}_{4}{ }^{+}$ turnover, followed by the urea-treated treatments (TR4 and TR5) and finally, the control. The treatment with bunds behaved similarly to those receiving mineral $\mathrm{N}$. The amount of injected urea did not affect the peak $\mathrm{NH}_{4}{ }^{+}$level.

\section{$\mathrm{NH}_{4}{ }^{+}$variability during the paddy cropping season Content of $\mathrm{NH}_{4}^{+}$in valley Middle}

The fluctuation in $\mathrm{NH}_{4}{ }^{+}$concentrations at the Middle site across the rice-cropping season is depicted in Figure 5. At week 0 (shortly after rice planting), the $\mathrm{NH}_{4}{ }^{+}$content differed modestly between treatments.

TR5 had the highest concentration $(0.02731 \mathrm{~g} / \mathrm{kg}$ soil $)$, and TR2 had the lowest $(0.00993 \mathrm{~g} / \mathrm{kg}$ soil). TR4, TR5, and TR6 levels at week 0 were significantly greater $(\mathrm{P}=0.05)$ than the values for the other treatments (Table 9). Additionally, it is critical to highlight the significant differences in $\mathrm{NH}_{4}{ }^{+}$concentrations that occurred between treatments even during the following phases of the rice cropping season.

In general, the $\mathrm{NH}_{4}{ }^{+}$content decreased over the 16 weeks in the majority of the treatments. TR4 and TR5 behaved differently at week $8(0.009733$ and $0.03038 \mathrm{~g} / \mathrm{kg}$ soil) but then followed a similar trend of declining $\mathrm{NH}_{4}{ }^{+}$ concentration until week 16. The greatest drop in $\mathrm{NH}_{4}{ }^{+}$ concentration throughout the 16 weeks was observed in TR5 $(0.024746 \mathrm{~g} / \mathrm{kg}$ soil $)$, while the smallest decrease was observed in TR3 $(0.007912 \mathrm{~g} / \mathrm{kg}$ soil $)$.

While TR1, TR2, and TR3 had significantly lower $\mathrm{NH}_{4}{ }^{+}$levels throughout the early phases of the rice cropping season, TR1 had significantly greater $\mathrm{NH}_{4}{ }^{+}$levels by week 16 compared to the other treatments (Table 9).

\section{Content of $\mathrm{NH}_{4}^{+}$in valley Fringe}

The variance in $\mathrm{NH}_{4}{ }^{+}$concentrations at the Fringe site is illustrated in Figure 6. At week 0, TR5 $(0.02987 \mathrm{~g} / \mathrm{kg}$ soil) had the greatest $\mathrm{NH}_{4}{ }^{+}$content $(0.01841 \mathrm{~g} / \mathrm{kg}$ soil). TR1 and TR2 had the lowest values, while TR3 had the highest. These differences from the rest were statistically significant $(\mathrm{P}=0.05)$. TR2, TR3, and TR5 continued to exhibit the same tendency throughout the cropping season, as demonstrated by weeks 8 and 16 (Table 10). Nevertheless, similar to the Middle site, TR1 maintained much higher $\mathrm{NH}_{4}{ }^{+}$values during the same period.

The $\mathrm{NH}_{4}{ }^{+}$content of TR4 and TR5 soils increased significantly at week $8(0.009513 \mathrm{~g} / \mathrm{kg}$ soil from 0.003032 $\mathrm{g} / \mathrm{kg}$ soil at week 6 for TR4 and $0.027823 \mathrm{~g} / \mathrm{kg}$ soil from $0.003032 \mathrm{~g} / \mathrm{kg}$ soil at week 6 for TR5, respectively) (Figure 6). Statistics indicated that these peak values were statistically significant $(P=0.05)$. Apart from the unique phenomena observed at week 8 for TR4 and 5, the general trend for the remaining treatments was a drop in $\mathrm{NH}_{4}^{+}$ content from week 0 to week 6 or 8 , a minor increase in the same at week 10, and stagnation for the remainder of the cropping season until week 16 .

Table 7. Effect of crop management interventions on the $\mathrm{NH}_{4}{ }^{+}$ content during the pre-paddy growing season at the Middle site

\begin{tabular}{lcccc}
\hline \multirow{2}{*}{ Treatment } & \multicolumn{4}{c}{$\mathbf{N H}_{4}{ }^{+}$content $(\mathbf{g} / \mathbf{k g}$ soil) } \\
\cline { 2 - 5 } TR1 & Week 0 & Week 1 & Week 6 & Week 10 \\
TR2 & $0.00158 \mathrm{ab}$ & $0.002476 \mathrm{a}$ & $0.000204 \mathrm{a}$ & $0.002154 \mathrm{ab}$ \\
TR3 & $0.000698 \mathrm{a}$ & $0.000992 \mathrm{a}$ & $0.000514 \mathrm{a}$ & $0.002836 \mathrm{ab}$ \\
TR4 & $0.001121 \mathrm{ab}$ & $0.001242 \mathrm{a}$ & $0.002058 \mathrm{ab}$ & $0.004212 \mathrm{bc}$ \\
TR5 & $0.000958 \mathrm{a}$ & $0.001121 \mathrm{a}$ & $0.004525 \mathrm{~b}$ & $0.001955 \mathrm{ab}$ \\
TR6 & $0.002158 \mathrm{~b}$ & $0.001383 \mathrm{a}$ & $0.007207 \mathrm{c}$ & $0.00361 \mathrm{abc}$ \\
& & & & \\
Mean & 0.001262 & 0.001135 & 0.00314 & 0.00337 \\
F statistics & 0.019 & 0.1 & 0.001 & 0.002 \\
L.S.D & 0.0007662 & 0.000663 & 0.001666 & 0.00141 \\
CV(\%) & 5.3 & 14.4 & 5.3 & 24.7 \\
\hline N. & & &
\end{tabular}

Note: Means in the same column followed by the same letter(s) are not significantly different according to the Tukey test $(\mathrm{P}=$ $0.05)$.

Table 8. Effect of crop management interventions on the $\mathrm{NH}_{4}{ }^{+}$ content at selected periods during the pre-paddy growing season at the Fringe site

\begin{tabular}{lcccc}
\hline \multirow{2}{*}{ Treatment } & \multicolumn{4}{c}{ NH $_{\mathbf{4}}{ }^{+}$content $(\mathrm{g} / \mathrm{kg}$ soil $)$} \\
\cline { 2 - 5 } & Week 0 & Week 1 & Week 6 & Week 10 \\
\hline TR1 & $0.001955 \mathrm{ab}$ & $0.002431 \mathrm{a}$ & $0.00013286 \mathrm{a}$ & $0.005934 \mathrm{~b}$ \\
TR2 & $0.003805 \mathrm{c}$ & $0.004176 \mathrm{a}$ & $0 \mathrm{a}$ & $0.003988 \mathrm{a}$ \\
TR3 & $0.003314 \mathrm{c}$ & $0.004379 \mathrm{a}$ & $0 \mathrm{a}$ & $0.004174 \mathrm{a}$ \\
TR4 & $0.003126 \mathrm{bc}$ & $0.004973 \mathrm{a}$ & $0 \mathrm{a}$ & $0.004524 \mathrm{a}$ \\
TR5 & $0.003471 \mathrm{c}$ & $0.003836 \mathrm{a}$ & $0 \mathrm{a}$ & $0.004595 \mathrm{a}$ \\
TR6 & $0.001371 \mathrm{a}$ & $0.002349 \mathrm{a}$ & $0 \mathrm{a}$ & $0.003742 \mathrm{a}$ \\
& & & & \\
Mean & 0.00284 & 0.00369 & 0.000022 & 0.00449 \\
F statistic & 0.9 & 0.097 & 0.465 & 0.158 \\
L.S.D & 0.000871 & 0.002115 & 0.000171 & 0.001713 \\
CV $(\%)$ & 0.9 & 8.4 & 21 & 4.4 \\
\hline N & &
\end{tabular}

Note: Means in the same column followed by the same letter(s) are not significantly different according to the Tukey test $(\mathrm{P}=$ $0.05)$ 


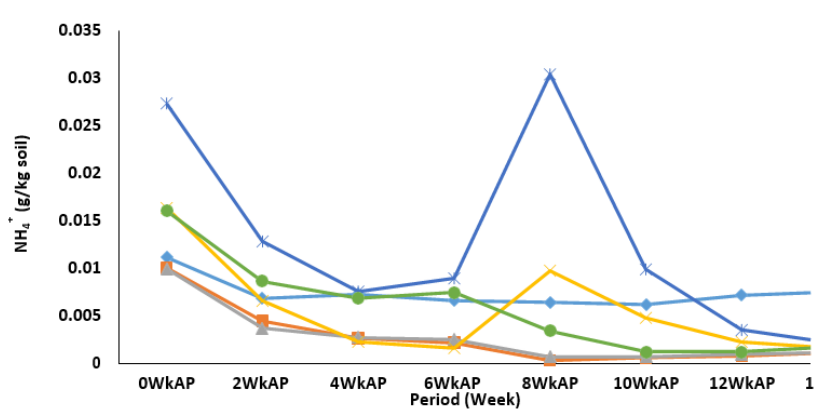

Figure 5. $\mathrm{NH}_{4}{ }^{+}$content during the paddy-cropping season at the Middle site. WKAP: Week after transplanting rice

Table 9. Effect of crop management interventions on the $\mathrm{NH}_{4}{ }^{+}$ content during the paddy-cropping season at the Middle site

\begin{tabular}{lccc}
\hline \multirow{2}{*}{ Treatment } & \multicolumn{3}{c}{$\mathbf{N H}_{\mathbf{4}}{ }^{+}$content $\mathbf{~ g / k g ~ s o i l ) ~}$} \\
\cline { 2 - 4 } & Week 0 & Week 8 & Week 16 \\
\hline TR1 & $0.01112 \mathrm{a}$ & $0.0064 \mathrm{bc}$ & $0.008739 \mathrm{~b}$ \\
TR2 & $0.01003 \mathrm{a}$ & $0.000289 \mathrm{a}$ & $0.001486 \mathrm{a}$ \\
TR3 & $0.00993 \mathrm{a}$ & $0.000669 \mathrm{a}$ & $0.001465 \mathrm{a}$ \\
TR4 & $0.01633 \mathrm{~b}$ & $0.009733 \mathrm{c}$ & $0.002018 \mathrm{a}$ \\
TR5 & $0.02731 \mathrm{c}$ & $0.030381 \mathrm{~d}$ & $0.002914 \mathrm{a}$ \\
TR6 & $0.016 \mathrm{~b}$ & $0.003369 \mathrm{ab}$ & $0.002564 \mathrm{a}$ \\
Mean & 0.01512 & 0.00847 & 0.0032 \\
F statistic & 0.001 & 0.001 & 0.001 \\
L.S.D & 0.001891 & 0.002127 & 0.001252 \\
CV $(\%)$ & 3 & 1.5 & 1.9 \\
\hline
\end{tabular}

*Means in the same column followed by the same letter(s) are not significantly different according to the Tukey test $(\mathrm{P}=0.05)$

\section{Effect of crop management interventions on the variation of $\mathrm{NO}_{3}{ }^{-}$content}

The data illustrating the changes in $\mathrm{NO}_{3}{ }^{-}$content in the examined soils are divided into two time periods: the prepaddy growing season and the paddy cropping season.

\section{$\mathrm{NO}_{3}{ }^{-}$content during the pre-rice cropping period}

The $\mathrm{NO}_{3}{ }^{-}$the content of both the Middle and Fringe locations is included in the results reported here.

\section{$\mathrm{NO}_{3}{ }^{-}$content at Middle site}

At the start of the rainy season, the $\mathrm{NO}_{3}{ }^{-}$concentration varied slightly between treatments, with TR6 and TR2 having the highest and lowest levels (0.002951 and $0.002324 \mathrm{~g} / \mathrm{kg}$ soil), respectively (Figure 7).

The $\mathrm{NO}_{3}{ }^{-}$level in all treatments fell to $0 \mathrm{~g} / \mathrm{kg}$ soil within two weeks. Depending on the individual treatment, there was a beneficial shift in $\mathrm{NO}_{3}{ }^{-}$content between weeks 3 and 5 .

This increase persisted from week 0 to week 10 . However, the pattern varied according to treatment. However, these increases in $\mathrm{NO}_{3}^{-}$were not statistically significant $(\mathrm{P}=0.05)$, except at week 10 , when the $\mathrm{NO}_{3}{ }^{-}$ value in TR1 $(0.000621 \mathrm{~g} / \mathrm{kg}$ soil $)$ was statistically considerably lower than the value observed in the other treatments (Table 11).

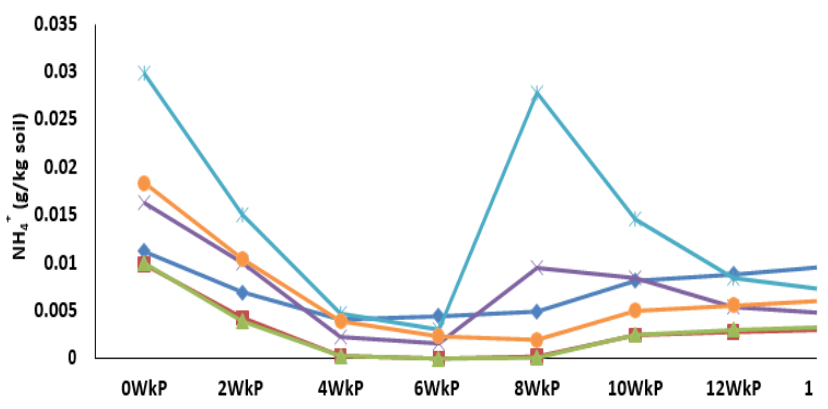

Figure 6. $\mathrm{NH}_{4}{ }^{+}$content during the paddy-cropping season at the Fringe site. WKP: Week after transplanting rice

Table 10. Effect of crop management interventions on the $\mathrm{NH}_{4}{ }^{+}$ content during the paddy-cropping season at the Fringe site

\begin{tabular}{lccc}
\hline \multirow{2}{*}{ Treatment } & \multicolumn{3}{c}{$\mathbf{N H}_{\mathbf{4}}{ }^{+}$content $\mathbf{~ g / k g ~ s o i l )}$} \\
\cline { 2 - 4 } & Week 0 & Week 8 & Week 16 \\
\hline TR1 & $0.01123 \mathrm{a}$ & $0.00492 \mathrm{~b}$ & $0.010551 \mathrm{~d}$ \\
TR2 & $0.00987 \mathrm{a}$ & $0.000213 \mathrm{a}$ & $0.003653 \mathrm{a}$ \\
TR3 & $0.01002 \mathrm{a}$ & $0.000083 \mathrm{a}$ & $0.003627 \mathrm{a}$ \\
TR4 & $0.01633 \mathrm{~b}$ & $0.009513 \mathrm{c}$ & $0.005379 \mathrm{ab}$ \\
TR5 & $0.02987 \mathrm{c}$ & $0.027823 \mathrm{~d}$ & $0.008084 \mathrm{c}$ \\
TR6 & $0.01841 \mathrm{~b}$ & $0.001975 \mathrm{ab}$ & $0.007236 \mathrm{bc}$ \\
Mean & 0.01595 & 0.00742 & 0.00642 \\
F statistic & 0.001 & 0.001 & 0.001 \\
L.S.D & 0.001966 & 0.001805 & 0.001361 \\
CV $(\%)$ & 2.2 & 1.9 & 4.6 \\
\hline
\end{tabular}

*Means in the same column followed by the same letter(s) are not significantly different according to the Tukey test $(\mathrm{P}=0.05)$

$\mathrm{NO}_{3}{ }^{-}$content at the Fringe site

Figure 8 illustrates the $\mathrm{NO}_{3}{ }^{-}$concentration at the Fringe site during the pre-paddy growing season. TR6 had the maximum concentration $(0.002104 \mathrm{~g} / \mathrm{kg}$ soil $)$ in week 0 $(0.002104 \mathrm{~g} / \mathrm{kg}$ soil $)$. The remainder of the treatments contained almost no $\mathrm{NO}_{3}{ }^{-}$.

Between weeks 1 and 7, except TR6, hardly any $\mathrm{NO}_{3}{ }^{-}$ was detected in the root zone for most imposed treatments. An increase in $\mathrm{NO}_{3}{ }^{-}$occurred differentially between weeks 7 and 10. The differences, however, were not statistically significant $(\mathrm{P}=0.05)$ (Table 12$)$. Thus, by week 10 , the root zone $\mathrm{NO}_{3}{ }^{-}$concentration ranged between 0.000453 (TR 4) and 0.0010683 (TR5) g/kg soil.

\section{$\mathrm{NO}_{3}{ }^{-}$content during the paddy cropping season}

$\mathrm{NO}_{3}{ }^{-}$content at Middle site

The following qualities can be seen in these results: Initial relatively high $\mathrm{NO}_{3}^{-}$values that vary among treatments, dividing the latter into three categories that are statistically significantly different $(\mathrm{P}=0.05)$ (Table 13), a decline of $\mathrm{NO}_{3}{ }^{-}$to achieve absolute or close to $0 \mathrm{~g} / \mathrm{kg}$ soil from week 8 to the rest of the cropping season (except for TR4 and TR5, which showed a remarkable rise in $\mathrm{NO}_{3}{ }^{-}$at week 8) (Figure 9).

TR5 $\left(0.010681 \mathrm{~g} / \mathrm{kg}\right.$ soil) had the greatest $\mathrm{NO}_{3}^{-}$the level at week 0 , followed by TR4 $(0.005722 \mathrm{~g} / \mathrm{kg}$ soil $)$. The two treatments were statistically different from the others 
$(\mathrm{P}=0.05)$ (Table 13). The $\mathrm{NO}_{3}^{-}$level in TR5 increased dramatically at week 8 , reaching $0.011948 \mathrm{~kg} / \mathrm{kg}$ from 0 $\mathrm{g} / \mathrm{kg}$ at week 6 . TR4 showed a similar trend $(0.00675 \mathrm{~g} / \mathrm{kg}$ soil at week 8 compared to $0 \mathrm{~g} / \mathrm{kg}$ soil at week 6 ).

Following that, the $\mathrm{NO}_{3}{ }^{-}$levels dropped to near $0 \mathrm{~g} / \mathrm{kg}$ soil in both cases by week 12 and stayed nearly constant until week 16. From week 6 to week 16, TR1 experienced a small but considerable increase in $\mathrm{NO}_{3}$.

\section{$\mathrm{NO}_{3}{ }^{-}$content at the Fringe site}

With two exceptions: a considerably higher $(\mathrm{P}=0.05)$ TR1 value than the other treatments at week 16 and an abrupt increase in $\mathrm{NO}_{3}{ }^{-}$content in TR3 at week 10, the $\mathrm{NO}_{3}{ }^{-}$fluctuation during the rice cropping season approximated that of the Middle site (Figure 10).

TR5 had the greatest $\mathrm{NO}_{3}{ }^{-}$value $(0.009302 \mathrm{~g} / \mathrm{kg}$ soil $)$ at week 0 , followed by TR6 $(0.005841 \mathrm{~g} / \mathrm{kg}$ soil $)$, and TR 2 had the lowest $\mathrm{NO}_{3}{ }^{-}$value $(0.00242 \mathrm{~g} / \mathrm{kg}$ soil) (Table 14$)$.

\section{Effect of hydrological conditions on the $\mathrm{NH}_{4}{ }^{+}$and $\mathrm{NO}_{3}{ }^{-}$ variation during the paddy growing season}

This section discusses the findings of $\mathrm{NH}_{4}{ }^{+}$and $\mathrm{NO}_{3}$ content measurements as a function of both imposed treatments and hydrologic conditions. These are the

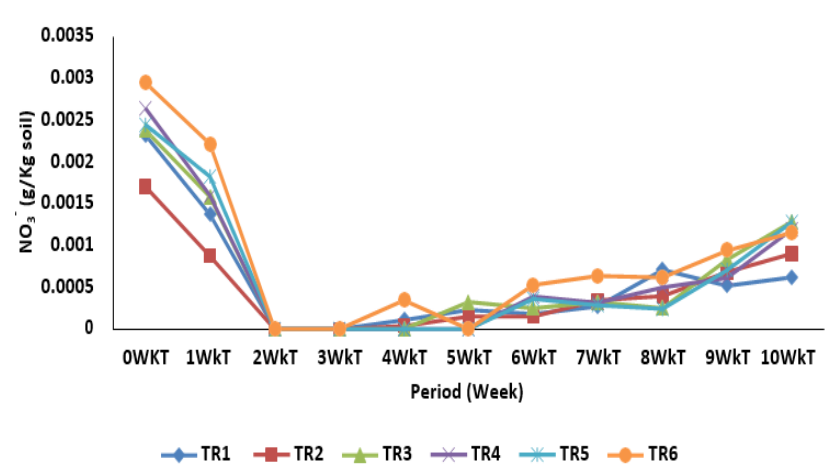

Figure 7. $\mathrm{NO}_{3}{ }^{-}$content during the pre-paddy growing season at the Middle site. WKT: Week before transplanting rice (dry-wet transition weeks)

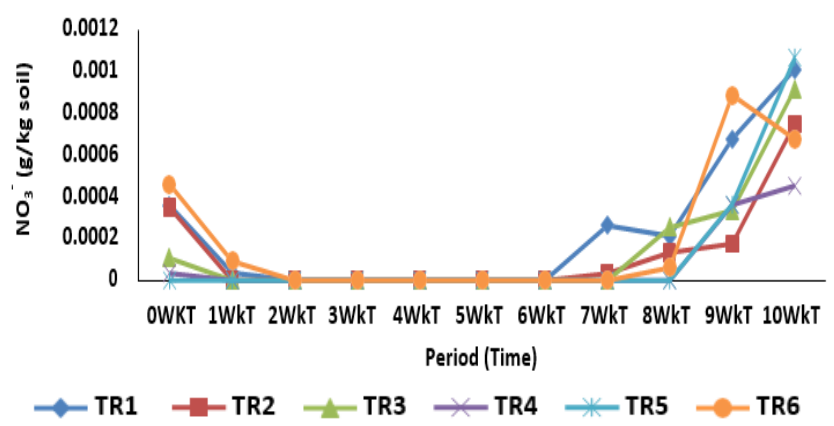

Figure 8. $\mathrm{NO}_{3}{ }^{-}$content during the pre-paddy growing season at the Fringe site. WKT. The week before transplanting rice (drywet transition weeks) aggregated results from the hydrological conditions examined (Middle and Fringe sites). Due to the similar magnitudes and trends in the content of both $\mathrm{NH}_{4}^{+}$and $\mathrm{NO}_{3}{ }^{-}$values in the treatments between the pooled values (Middle and Fringe combined) and those from individual sites (Middle or Fringe), as presented previously, then this will demonstrate the effect of hydrological conditions on $\mathrm{NH}_{4}{ }^{+}$and $\mathrm{NO}_{3}{ }^{-}$content.

Effect of hydrological conditions on the content of $\mathrm{NH}_{4}{ }^{+}$

$\mathrm{NH}_{4}{ }^{+}$values for a given week are shown in Figure 11 at both the Middle and Fringe sites. Tables 15 and 16 illustrate statistical comparisons of the $\mathrm{NH}_{4}{ }^{+}$concentrations at the two sites. Throughout the 16-week study period, there was no significant difference between the sites with varying hydrological conditions.

Thus, regardless of the treatment used, there was no statistically significant change in $\mathrm{NH}_{4}{ }^{+}$concentration between the Middle and Fringe sites during the ricegrowing season. As a result, these findings imply that the site's hydrology had no discernible effect on the $\mathrm{NH}_{4}{ }^{+}$ condition.

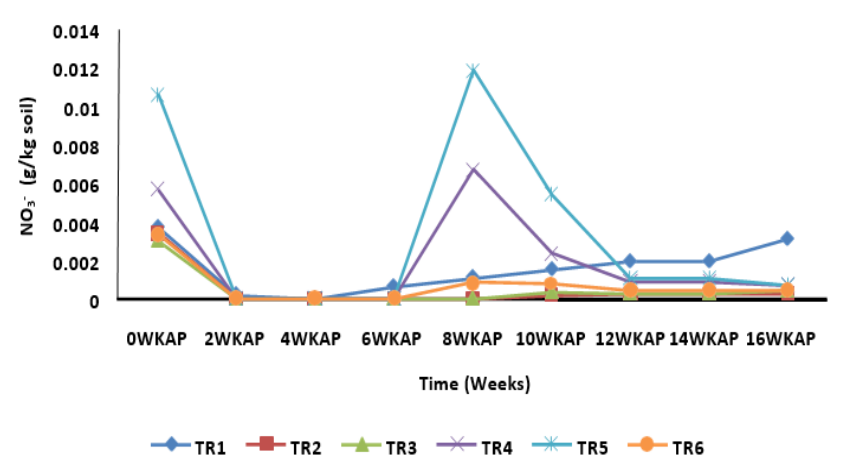

Figure 9. $\mathrm{NO}_{3}{ }^{-}$content the rice paddy-cropping season at the Middle site. WKAP: Weeks after transplanting rice

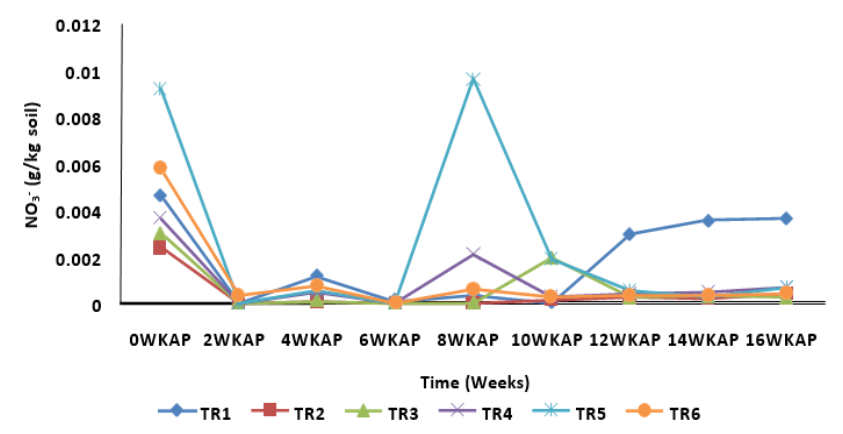

Figure 10. $\mathrm{NO}_{3}{ }^{-}$content the rice paddy-cropping season at the Fringe site. WKAP: Week after transplanting rice 
Table 11. Effect of crop management interventions on the $\mathrm{NO}_{3}$ content during the pre-paddy growing season at the Middle site

\begin{tabular}{lccc}
\hline \multirow{2}{*}{ Treatment } & \multicolumn{3}{c}{ NO3 $^{-}$content $(\mathbf{g} / \mathbf{k g}$ soil) } \\
\cline { 2 - 4 } & Week 0 & Week 6 & Week 10 \\
\hline TR1 & $0.002324 \mathrm{a}$ & $0.0001821 \mathrm{a}$ & $0.000621 \mathrm{a}$ \\
TR2 & $0.001706 \mathrm{a}$ & $0.000153 \mathrm{a}$ & $0.000903 \mathrm{ab}$ \\
TR3 & $0.002383 \mathrm{a}$ & $0.0002505 \mathrm{a}$ & $0.001285 \mathrm{~b}$ \\
TR4 & $0.002645 \mathrm{a}$ & $0.0003933 \mathrm{a}$ & $0.001195 \mathrm{ab}$ \\
TR5 & $0.002448 \mathrm{a}$ & $0.0003612 \mathrm{a}$ & $0.001283 \mathrm{ab}$ \\
TR6 & $0.002951 \mathrm{a}$ & $0.0005301 \mathrm{a}$ & $0.001159 \mathrm{ab}$ \\
& & & \\
Mean & 0.00241 & 0.000312 & 0.001075 \\
F statistics & 0.101 & 0.08 & 0.023 \\
L.S.D & 0.000822 & 0.000271 & 0.000396 \\
CV $(\%)$ & 9.2 & 10.3 & 5.3 \\
\hline No: & &
\end{tabular}

Note: Means in the same column followed by the same letter(s) are not significantly different according to the Tukey test $(\mathrm{P}=$ $0.05)$

Table 12. Effect of crop management interventions on the $\mathrm{NO}_{3}$ content during the pre-paddy growing season at the Fringe site

\begin{tabular}{lccc}
\hline \multirow{2}{*}{ Treatment } & \multicolumn{3}{c}{ NO3 $^{-}$content $(\mathbf{g} / \mathbf{k g}$ soil) } \\
\cline { 2 - 4 } & Week 0 & Week 6 & Week 10 \\
\hline TR1 & $0.0003604 \mathrm{a}$ & $0 \mathrm{a}$ & $0.0010126 \mathrm{a}$ \\
TR2 & $0.0003482 \mathrm{a}$ & $0 \mathrm{a}$ & $0.0007507 \mathrm{a}$ \\
TR3 & $0.0001057 \mathrm{a}$ & $0 \mathrm{a}$ & $0.0009195 \mathrm{a}$ \\
TR4 & $0.0000337 \mathrm{a}$ & $0 \mathrm{a}$ & $0.000453 \mathrm{a}$ \\
TR5 & $0 \mathrm{a}$ & $0 \mathrm{a}$ & $0.0010683 \mathrm{a}$ \\
TR6 & $0.00004594 \mathrm{a}$ & $0 \mathrm{a}$ & $0.0006769 \mathrm{a}$ \\
& & & \\
Mean & 0.000492 & 0 & 0.000814 \\
F statistic & 0.001 & 0 & 0.155 \\
L.S.D & 0.0003849 & 0 & 0.000509 \\
CV $(\%)$ & 30.3 & 0 & 17.3 \\
\hline Not & &
\end{tabular}

Note: Means in the same column followed by the same letter(s) are not significantly different according to the Tukey test $(\mathrm{P}=$ $0.05)$

Table 13. Effect of crop management interventions on the $\mathrm{NO}_{3}$ content during the rice-cropping season at the Middle site

\begin{tabular}{lccc}
\hline \multirow{2}{*}{ Treatment } & \multicolumn{3}{c}{ NO3 $^{-}$content $(\mathbf{g} / \mathbf{k g}$ soil) } \\
\cline { 2 - 4 } & Week 0 & Week 8 & Week 16 \\
\hline TR1 & $0.00378 \mathrm{a}$ & $0.001113 \mathrm{a}$ & $0.0031145 \mathrm{~b}$ \\
TR2 & $0.003474 \mathrm{a}$ & $0 \mathrm{a}$ & $0.0002873 \mathrm{a}$ \\
TR3 & $0.003075 \mathrm{a}$ & $0 \mathrm{a}$ & $0.000463 \mathrm{a}$ \\
TR4 & $0.005722 \mathrm{~b}$ & $0.00675 \mathrm{~b}$ & $0.0007468 \mathrm{a}$ \\
TR5 & $0.010681 \mathrm{c}$ & $0.011948 \mathrm{c}$ & $0.0007007 \mathrm{a}$ \\
TR6 & $0.00336 \mathrm{a}$ & $0.000852 \mathrm{a}$ & $0.00047 \mathrm{a}$ \\
& & & \\
Mean & 0.00502 & 0.00344 & 0.00096 \\
F-Statistic & 0.001 & 0.001 & 0.001 \\
L.S.D. & 0.000997 & 0.001291 & 0.000985 \\
CV $(\%)$ & 2.2 & 3.8 & 14.9 \\
\hline Not & &
\end{tabular}

Note: Means in the same column followed by the same letter(s) are not significantly different according to the Tukey test $(\mathrm{P}=$ $0.05)$
Table 14. Effect of crop management interventions on the $\mathrm{NO}_{3}{ }^{-}$ content during the rice paddy-cropping season at the Fringe site

\begin{tabular}{|c|c|c|c|}
\hline \multirow[t]{2}{*}{ Treatment } & \multicolumn{2}{|c|}{$\mathrm{NO3}^{-}$content (g/kg soil) } & \multirow[b]{2}{*}{ Week 16} \\
\hline & Week 0 & Week 8 & \\
\hline 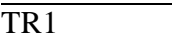 & $0.004646 \mathrm{a}$ & $0.000354 \mathrm{a}$ & $0.003662 b$ \\
\hline TR2 & $0.00242 \mathrm{a}$ & $0 \mathrm{a}$ & $0.000408 \mathrm{a}$ \\
\hline TR3 & $0.003047 \mathrm{a}$ & $0 \mathrm{a}$ & $0.000238 \mathrm{a}$ \\
\hline TR4 & $0.003686 \mathrm{a}$ & $0.002085 \mathrm{a}$ & $0.000663 \mathrm{a}$ \\
\hline TR5 & $0.009302 b$ & $0.009691 b$ & $0.000691 \mathrm{a}$ \\
\hline TR6 & $0.005841 \mathrm{ab}$ & $0.000643 a$ & $0.000402 \mathrm{a}$ \\
\hline Mean & 0.00482 & 0.00213 & 0.00101 \\
\hline F statistic & 0.001 & 0.001 & 0.001 \\
\hline L.S.D & 0.002291 & 0.001988 & 0.001029 \\
\hline $\mathrm{CV}(\%)$ & 13.4 & 20.6 & 22.9 \\
\hline
\end{tabular}

Note: Means in the same column followed by the same letter(s) are not significantly different according to the Tukey test $(\mathrm{P}=$ $0.05)$

Table 15. Two-way ANOVA for $\mathrm{NH}_{4}^{+}$content comparison between the Middle and Fringe sites at week 0 .

\begin{tabular}{lccccc}
\hline $\begin{array}{l}\text { Variate: } \mathbf{~ N H}_{\mathbf{4}}^{+} \\
\text {source of variation }\end{array}$ & D.F. & S.S. & \multicolumn{2}{c}{ M.S. } & \multicolumn{2}{c}{ V.R. F PR. } \\
\hline Treatment & 5 & $2.991 \mathrm{E}-03$ & $5.983 \mathrm{E}-04$ & 81.13 & $<.001$ \\
Block (site) & 1 & $4.382 \mathrm{E}-06$ & $4.382 \mathrm{E}-06$ & 0.59 & 0.448 \\
Treatment Block & 5 & $1.641 \mathrm{E}-04$ & $3.283 \mathrm{E}-05$ & 4.45 & 0.005 \\
Residual & 24 & $1.770 \mathrm{E}-04$ & $7.374 \mathrm{E}-06$ & & \\
Total & 35 & $3.337 \mathrm{E}-03$ & & & \\
\hline
\end{tabular}

Table 16. Two-way ANOVA for $\mathrm{NH}_{4}^{+}$content comparison between the Middle and Fringe sites at week 6 .

\begin{tabular}{lccccc}
\hline $\begin{array}{l}\text { Variate: } \mathbf{N H}_{4}{ }^{+} \\
\text {source of variation }\end{array}$ & D.F. & S.S. & M.S. & V.R. F PR. \\
\hline Replicate stratum & 2 & $2.166 \mathrm{E}-05$ & $1.083 \mathrm{E}-05$ & 2.04 & \\
Treatment & 5 & $2.050 \mathrm{E}-04$ & $4.100 \mathrm{E}-05$ & 7.71 & $<.001$ \\
Block (site) & 1 & $1.538 \mathrm{E}-10$ & $1.538 \mathrm{E}-10$ & 0.00 & 0.996 \\
Treatment Block & 5 & $7.124 \mathrm{E}-06$ & $1.425 \mathrm{E}-06$ & 0.27 & 0.926 \\
Residual & 22 & $1.170 \mathrm{E}-04$ & $5.317 \mathrm{E}-06$ & & \\
Total & 35 & $3.507 \mathrm{E}-04$ & & & \\
\hline
\end{tabular}

Effect of the hydrological conditions on the root zone $\mathrm{NO}_{3}$ content

The fluctuation in $\mathrm{NO}_{3}{ }^{-}$concentration between the Middle and Fringe locations across the 16-week study period is depicted in Figure 12. There was no significant variation in NO3- content for the trial duration. This is illustrated in Table 17.

The statistical study results on $\mathrm{NO}_{3}$ indicated no significant differences between the Middle and the Fringe in the latter periods (Week 0 to Week 16). However, the interaction between blocks and treatments was statistically significant in certain weeks. As a result of these findings, it is concluded that the site's hydrology had no discernible effect on the $\mathrm{NO}_{3}{ }^{-}$status. 
Table 17. Two-way ANOVA for $\mathrm{NO}_{3}^{-}$content comparison between the Middle and Fringe sites at week 0

\begin{tabular}{lcccccc}
\hline $\begin{array}{l}\text { Variate: } \mathbf{N O}_{3}^{-} \\
\text {source of variation }\end{array}$ & D.F. & S.S. & M.S. & \multicolumn{2}{c}{ V.R. F PR. } \\
\hline Replicate stratum & 2 & $2.465 \mathrm{E}-06$ & $1.233 \mathrm{E}-06$ & 1.26 & \\
Treatment & 5 & $2.023 \mathrm{E}-04$ & $4.046 \mathrm{E}-05$ & 41.24 & $<.001$ \\
Block (site) & 1 & $3.309 \mathrm{E}-07$ & $3.309 \mathrm{E}-07$ & 0.34 & 0.567 \\
Treatment.Block & 5 & $2.077 \mathrm{E}-05$ & $4.154 \mathrm{E}-06$ & 4.23 & 0.008 \\
Residual & 22 & $2.158 \mathrm{E}-05$ & $9.810 \mathrm{E}-07$ & & \\
Total & 35 & $2.474 \mathrm{E}-04$ & & & \\
\hline
\end{tabular}

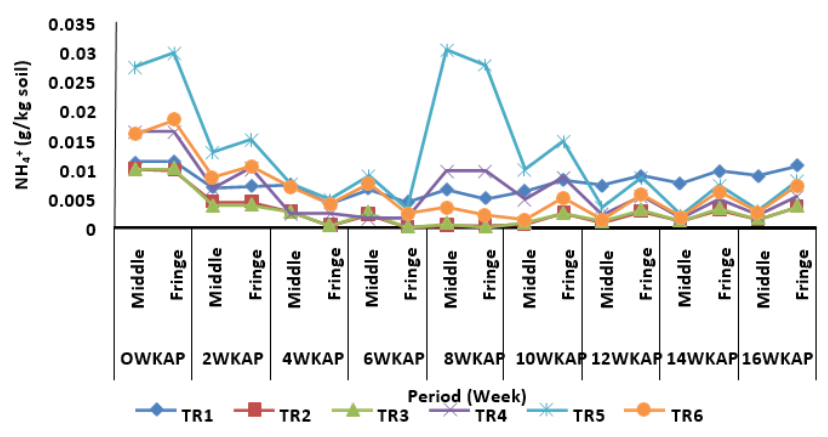

Figure 11. $\mathrm{NH}_{4}{ }^{+}$content in the different treatments at the Middle and Fringe sites during the paddy-growing season

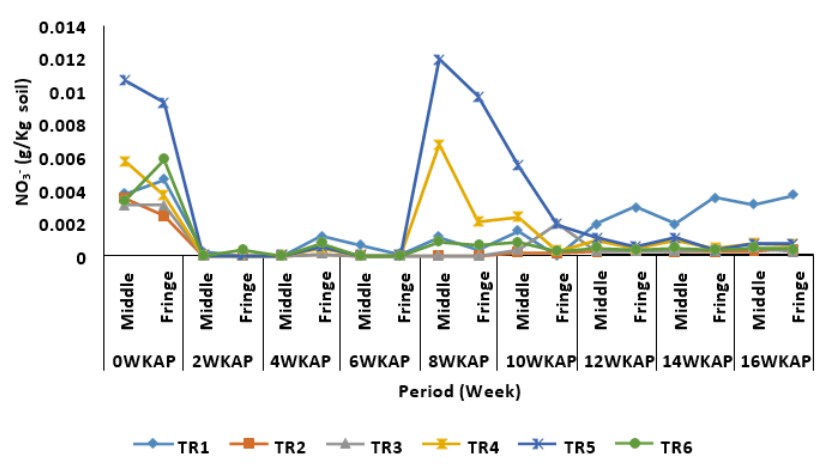

Figure 12. $\mathrm{NO}_{3}{ }^{-}$content in the different treatments at the Middle and Fringe sites during the paddy-growing season

\section{Discussion}

\section{Effect of crop management interventions on the Variation of $\mathrm{NH}_{4}{ }^{+}$content}

Variation of $\mathrm{NH}_{4}^{+}$during the pre-rice growing season (drywet transition period) at both sites; Middle and Fringe sites

These results are described independently for each of the analyzed locations and then compared to one another. Additionally, a comment is made on the seasonal fluctuation between the pre-rice growing season (wet-dry transitional period) and the protracted rain season, also known as the paddy cropping season.
The primary characteristics of the $\mathrm{NH}_{4}^{+}$variation during the wet-dry transitional season were an increase in $\mathrm{NH}_{4}{ }^{+}$during the initial period following the first rainfall to a peak value; a decline in $\mathrm{NH}_{4}{ }^{+}$to a value of $0 \mathrm{~g} / \mathrm{kg}$ soil $\mathrm{NH}_{4}{ }^{+}$content; and a subsequent rise near the season's end. This pattern is typical of both locations during the wet-dry season.

The increase in $\mathrm{NH}_{4}{ }^{+}$concentration following initial rains is related to mineralization, a process generally connected with the degradation of organic matter and the release of nutrients in their mineral form, including $\mathrm{NH}_{4}^{+}$ (Nziguheba et al. 2005; Sugihara et al. 2010 a,b). Therefore, differences in peak values across treatments can be interpreted as measuring the amount of mineralizable nitrogen in the substrate soil organic matter (Wang et al., 2004; Nziguheba et al., 2005).

Mineralization will often continue as long as the prevailing conditions, including the presence of a substrate, permit. The $\mathrm{pH}, \mathrm{C}: \mathrm{N}$ ratio, redox potential, microbial activity and biomass, electron acceptor availability, cation exchange capacity, amount and nature of clay, nature and amounts of salts, inputs and nature of organic materials, soil organic matter content, and quality, and supply of nutrients such as phosphorus (P), among others, all play a role in ammonium production in submerged rice soils (Deenik 2006; Inamura et al. 2009). Except for the organic matter content and perhaps the $\mathrm{C} / \mathrm{N}$ ratio, most of these variables were similar, if not identical, among treatments. It is self-evident that treatments fertilized with $\mathrm{N}$, organic or inorganic, should have generated more biomass than those that were not, resulting in significantly more mineralizable $\mathrm{N}$ and a significantly longer duration of obtaining the peak $\mathrm{NH}_{4}{ }^{+}$concentration (Kimetu et al. 2006). This appears to be the case at the Middle site, where TR6, TR5, and TR4 had some of the highest peak $\mathrm{NH}_{4}{ }^{+}$values compared to the other treatments. It is critical to note that mineralization happened equally in the Fringe and Middle sites, with significantly less pronounced differences between the treatments. The inconsistency in the peak $\mathrm{NH}_{4}{ }^{+}$content and the time required to reach it cannot be adequately explained. This may be partly explained by the much more significant percentage of water-filled pore space during the first three weeks. Additionally, changes in the rate of water loss by natural drainage following a rain occurrence were seen among treatments, a phenomenon that was not previously described. Between weeks 0 and 3, the soil at the Fringe site was drier, with percentage WFP values of $80.51 \%$ at week $0,86.05 \%$ at week 1 , and 79.85 and $76.55 \%$ at weeks 2 and 3 , respectively. These conditions are suboptimal for organic matter decomposition (Gilmour et al. 1977) and ammonification (Pal and Broadbent 1975). This may explain why the Middle site's percentage WFP values peaked at $53.89 \%$ during the period of peak mineralization. Linn and Doran (1984) demonstrated a linear relationship between microbial activity and WFP levels between $30 \%$ and $60 \%$, often the optimal moisture level for microbiologically regulated processes like mineralization. 
These results indicate that the mineralization period for peak $\mathrm{NH}_{4}{ }^{+}$production at the Middle site was between 3 and 6 weeks and between 1 and 3 weeks at the Fringe site. The difference is most likely due to changes in soil moisture conditions. The latter is more humid and has a percentage water saturation of greater than $60 \%$ during the first four weeks of the rain season. Additionally, mineralization occurred over a more extended period with a substantially higher peak $\mathrm{NH}_{4}{ }^{+}$in treatments with a greater biomass incorporation rate the previous season.

The parallelism in the decrease in $\mathrm{NH}_{4}{ }^{+}$levels between the Middle and Fringe sites suggests the presence of similar impacting variables. The decline can be attributed to a variety of processes, including plant uptake, leaching (where conditions permit) (Kimetu et al. 2006), volatilization (Jones et al. 2007), nitrification (Reddy and DeLaune 2008; Sahrawat 2010), deamination (Reddy and DeLaune 2008), decomposition (Reddy and DeLaune 2008), and decline in decomposable organic matter (Marschner 2008). The phenomenon is generally attributable to nitrification and plant uptake of both $\mathrm{NH}_{4}^{+}$ and $\mathrm{NO}_{3}{ }^{-}$in the first instance. The reason for linking the drop with nitrification is reinforced by the aerobic conditions prevalent during this period, as indicated by the elevated redox potential readings (Table 5). Numerous earlier investigations have linked redox levels greater than $+300 \mathrm{mV}$ to aerobic circumstances (Pezeshki and Delaune 2012) conducive to nitrification (Reddy and DeLaune 2008). The time of the $\mathrm{NH}_{4}^{+}$drop coincided with a significant decrease in soil moisture content (Table 3 ).

The percentage of water-filled pores (\% WFP) varied between $35.7 \%$ (week 6) to $29.57 \%$ during this period (Table 4). Under low soil moisture content conditions, microbial-mediated processes such as organic matter decomposition and mineralization occur at a low rate (Pal and Broadbent, 1975; Gilmour et al., 1977; Linn and Doran, 1984). Linn and Doran (1984) reported that at a concentration of $30 \%$ WFP, microbial activity is significantly decreased.

The rapid increase in $\mathrm{NH}_{4}^{+}$concentration in all treatments between weeks 9 and 10 is related to increased soil moisture. At week 10, the soil moisture status increased from $14.49 \%$ moisture content, or $29.57 \%$ WFP, to $34.67 \%(64.63 \%$ WFP). Linn and Doran (1984) concluded that the \% WFP value at week 10 is close to ideal for microbial-mediated processes like mineralization. At week 10 , the $\mathrm{NH}_{4}{ }^{+}$turnover reflects the soil's capacity to produce $\mathrm{NH}_{4}^{+}$before rice crop transplantation. This is consistent with previous discoveries that dry circumstances are optimal for the soil microbial biomass, which serves as both a nutrient sink and a source of nutrients in tropical ecosystems ahead of the following rain season (Sugihara et al. 2010a). At the Middle site, TR5 and TR3 outperformed the other treatments in terms of $\mathrm{NH}_{4}{ }^{+}$supply capacity, whereas TR1 outperformed the other treatments in terms of $\mathrm{NH}_{4}{ }^{+}$supply capacity.
$\mathrm{NH}_{4}{ }^{+}$variability during the paddy cropping season at both sites; Middle and Fringe site

Except for the treatments that received urea at week 7 after rice plant transplantation, the $\mathrm{NH}_{4}{ }^{+}$concentration decreased with time during the rice cropping season in this study. The drop in $\mathrm{NH}_{4}^{+}$over time is comparable to the decrease seen by Carmona et al. (2012) over a 91-day timeframe. The decline could be attributed in part to rice crop uptake (Ghosh and Bhat 1998) and possible leaching (Kimetu et al. 2006). Meng et al. (2014) observed significant $\mathrm{NH}_{4}{ }^{+}$losses beyond the $50 \mathrm{~cm}$ soil depth in both conventional and organic rice cultivation systems.

The observed reduction in $\mathrm{NH}_{4}{ }^{+}$from the first week onwards coincided with the presence of reducing soil conditions, as shown by the low $(+300 \mathrm{mV})$ redox values at both sites. Under these conditions, $\mathrm{NH}_{4}{ }^{+}$accumulates in the soil environment (Kimetu et al. 2006; Reddy and Delaune 2008), unless other factors such as $\mathrm{NH}_{4}{ }^{+}$ volatilization due to high $\mathrm{pH}$ (Loomis and Connor 1992), or leaching or displacement by runoff (Eder et al. 2015) have an effect. However, the $\mathrm{pH}$ values of the soils studied were low (5.8 and 6.1 for the Middle and Fringe sites, respectively). This is outside of that range. The most likely explanation for the observed low $\mathrm{NH}_{4}{ }^{+}$concentrations is slow nitrogen mineralization and/or leaching rate. It is widely established that low redox potential inhibits mineralization because only anaerobic or facultative anaerobic bacteria are capable of respiration (Pezeshki and Delaune 2012). This group of microorganisms has a limited capacity for carbon absorption and high energy requirements (Pezeshki and Delaune 2012). The limit for aerobic respiration is regarded to be redox levels greater than $+300 \mathrm{mV}$. (Rostaminia et al., 2011; Pezeshki and Delaune 2012). As a result, the rate of $\mathrm{N}$ mineralization is likewise low (Kimetu et al. 2006). This may account for the relatively low $\mathrm{NH}_{4}{ }^{+}$values observed during the season's first four to six weeks at the Middle and Fringe sites, respectively.

The abrupt increase in $\mathrm{NH}_{4}{ }^{+}$in TR4 and TR5 at week 8 was attributed to the application of ammonium fertilizer in week 7. In actuality, urea hydrolyzes to become $\mathrm{NH}_{4}{ }^{+}$ within 5-7 days (Dharmakeerthi and Thenabadu, 1996). This could account for the increased $\mathrm{NH}_{4}{ }^{+}$recorder values in TR4 and TR5 during week 8. Meng et al. (2014) measured $\mathrm{NH}_{4}{ }^{+}$fluxes in leached nitrogen following DAP (di-ammonium phosphate) and urea topdressing.

However, the level of $\mathrm{NH}_{4}{ }^{+}$in the treatment with 120 $\mathrm{kg} / \mathrm{ha}$ additional urea (TR5) was not significantly greater than in the treatment with $60 \mathrm{~kg} / \mathrm{ha}$ added urea (TR4). The former was thrice greater, indicating that other factors may have influenced the $\mathrm{NH}_{4}{ }^{+}$content over the period under consideration. These, however, remain unaddressed in this work. Given that the redox potential in the soil (root zone) was greater than $+300 \mathrm{mV}$ for the majority of the rice cropping season at the Middle site, these conditions were favorable for the oxidation of $\mathrm{NH}_{4}{ }^{+}$to $\mathrm{NO}_{3}{ }^{-}$(Pezeshki and Delaune 2012). This could account for not just the study's overall low $\mathrm{NH}_{4}{ }^{+}$levels but also the abrupt fall in $\mathrm{NH}_{4}{ }^{+}$in TR4 and 5 after week 8 . 
Although Meng et al. (2014) previously observed the release of $\mathrm{NH}_{4}{ }^{+}$in paddy paddies during the late cropping season, the fairly considerable accumulation of $\mathrm{NH}_{4}^{+}$in TR1 warrants additional investigation to ascertain the causal reasons.

The addition of organic $60 \mathrm{~kg}$ of inorganic nitrogen to the soil following lablab green manure incorporation (TR6) appeared not to affect the NH4+ concentration. These findings contradict numerous earlier research (Becker et al. 1995). Lablab decomposes into $\mathrm{NH}_{4}^{+}$around four to six weeks after being incorporated into the soil under aerobic circumstances (Pereira et al., 2016). Under anaerobic conditions, ammonification of lablab would take significantly longer and give far less $\mathrm{NH}_{4}{ }^{+}$(Becker et al. 1995). The lack of reaction in $\mathrm{NH}_{4}{ }^{+}$could be attributed to the low redox potential that prevailed throughout the early stages of rice cropping, as illustrated in Table 6 . Mineralization becomes a negative process in this case (Toure et al., 2009). This may account for the low level of $\mathrm{NH}_{4}{ }^{+}$production during the rice-cropping season. One could anticipate detecting some variations between TR6 and the other treatments, particularly those without additional nitrogen.

The pattern of $\mathrm{NH}_{4}{ }^{+}$variation at the Fringe site was strikingly similar to that at the Middle site. This is demonstrated by the overall drop in initial $\mathrm{NH}_{4}{ }^{+}$ concentration and the abrupt increase in $\mathrm{NH}_{4}{ }^{+}$content at week 8 for treatments with increased mineral N. Thus; these findings can be explained similarly to those from the Middle site, except a considerable rise in $\mathrm{NH}_{4}{ }^{+}$content in TR5 and TR6 toward the end of the rice-cropping season (week 12-16) at the Fringe site. The given data cannot explain this discrepancy; more research is required. This controversy warrants additional investigation.

The significantly elevated $\mathrm{NH}_{4}{ }^{+}$levels seen in treatments with additional urea can be attributed only to $\mathrm{N}$ intake. Previous research has demonstrated increased ammonium generation during the decomposition of agricultural wastes from fields that received mineral $\mathrm{N}$ fertilizer (Kimetu et al. 2006). The absence of a difference in $\mathrm{NH}_{4}{ }^{+}$concentrations in the treatment group that received lablab green manure contradicts earlier research (Becker et al. 1995; Yadvinder-Singh et al. 2005). The decrease in $\mathrm{NH}_{4}{ }^{+}$content during the first six to eight weeks of the rice cropping season could be attributed to crop growth requiring mineral $\mathrm{N}$ (Nascente et al., 2009).

\section{Effects of crop management interventions on the variation of $\mathrm{NO}_{3}{ }^{-}$content \\ $\mathrm{NO}_{3}{ }^{-}$variability during the pre-rice cropping season at both sites; Middle and Fringe site}

At both sites, the variation in $\mathrm{NO}_{3}{ }^{-}$content across the research period followed a similar pattern indicating some similarities in the environmental factors that determined the soil's $\mathrm{NO}_{3}{ }^{-}$state. At the Fringe and Middle sites, the $\mathrm{NO}_{3}{ }^{-}$ level rapidly decreased to $0 \mathrm{~g} / \mathrm{kg}$ soil within 1 and 2 weeks, respectively. Surprisingly, this occurred under a wide variety of moisture conditions. At the Middle site, soil moisture was relatively depleted, whereas it was relatively abundant at the Fringe location (Linn and Doran 1984).
This pattern does not represent the comparatively high ammonium levels produced in the Middle and Fringe sites during the 2 - 4 and 1- 3 weeks, respectively. There is an obvious distinction between the two. Assuming that the conditions, particularly at the Middle site, were aerobic, as indicated by the potential redox values for the period under discussion, one would expect spontaneous oxidation of the existing ammonium and hence a corresponding increase in the $\mathrm{NO}_{3}^{-}$level. The same was expected for soil moisture and, more specifically, redox potential at the Middle site. The disparity between these two characteristics cannot be accounted for. These findings contradict Zaman et al. (1999), who observed the highest nitrification rates in soil treated with $\mathrm{NH}_{4} \mathrm{Cl}$ compared to other treatments without additional ammonium.

The extremely low or absent $\mathrm{NO}_{3}{ }^{-}$levels between weeks 2 and 6 at the Fringe site and between weeks 2 and 5 at the Middle site cannot be well explained by current data. During this period, ammonium was abundant, particularly at the Middle site (Figure 3), and the moisture and redox potential were favorable for nitrification. It would be good to conduct a similar study that completely characterizes the destiny of $\mathrm{N}$. Increases in $\mathrm{NO}_{3}{ }^{-}$content from week 4 (Middle) to week 6 (Fringe site) matched to the process of nitrification (Kimetu et al. 2006). The distinction between treatments was observed only in TR1 and TR3 at week 10 when the $\mathrm{NO}_{3}^{-}$level was much higher than in the other treatments.

\section{$\mathrm{NO}_{3}{ }^{-}$variability during the paddy growing period at both sites; Middle and Fringe site}

$\mathrm{NO}_{3}{ }^{-}$tended to accumulate during the dry season at both sites. The increase in NO3 demonstrates this ${ }^{-}$content toward the conclusion of the pre-rice cropping season and the accompanying relatively high readings at the start (week 0) of the rice cropping season. This is most likely due to the conversion of $\mathrm{NH}_{4}^{+}$to $\mathrm{NO}_{3}{ }^{-}$in aerobic conditions (Smith 2010). It has been demonstrated that alternate rainy and dry seasons result in the production of ammonium and its subsequent oxidation to $\mathrm{NO}_{3}^{-}$(Pande 2005).

The accumulated NO3- rapidly decreased to 0 or close to $0 \mathrm{~g} / \mathrm{kg}$ soil within two weeks regardless of the treatment or site. This decrease in $\mathrm{NO}_{3}{ }^{-}$levels could be attributed to denitrification as a result of the low redox potential of the soil (Table 6). From week 0 to week 2, the redox potential changed from 237.0 to $204.8 \mathrm{mV}$ at the Middle site and from 195.3 to $209.2 \mathrm{mV}$ at the Fringe site. These redox values are within the range where $\mathrm{O}_{2}$ is scarce, supporting denitrification (Reddy and Patrick 1975).

The consequent low nitrate content at the Middle site from week 2 to week 10 in the treatments that did not receive mineral nitrogen (TR2, TR3, and TR6) would negatively affect the crop. The need for $\mathrm{N}$ is often strong during this time, notably during the booting stage, which corresponds to weeks 8 and 10 (Kimetu et al. 2006). TR4 and TR5, which received 60 and $120 \mathrm{~kg} \mathrm{~N} / \mathrm{ha}$, respectively, were the only treatments with significantly higher nitrate levels at the booting and grain filling stages. During the late cropping stage (weeks 12-16), all rice crop treatments 
(TR2, TR3, TR4, TR5, and TR6) exhibited almost minor $\mathrm{NO}_{3}{ }^{-}$. The low $\mathrm{NH} 4+$ content could partly explain this and the possibility of the crop absorbing any available $\mathrm{NH}_{4}{ }^{+}$ during the booting period (Olk et al. 1996; Nascente et al. 2009).

At the Fringe location, there was almost no $\mathrm{NO}_{3}{ }^{-}$in any of the week 2 treatments. During the tillering and booting stages, the same thing happened to all treatments without added mineral N (TR1, TR2, TR3, and TR6) (week 2 to 8). As was the case with the Middle site, the treatments with rice crops (TR2, TR3, TR4, TR5) experienced a general fall in $\mathrm{NO}_{3}{ }^{-}$content to nearly $0 \mathrm{~g} / \mathrm{kg}$ soil during the late cropping stage (week 12 to 16 ). This was mainly due to the soil's low $\mathrm{NH}_{4}{ }^{+}$level, particularly in treatments that did not get mineral $\mathrm{N}$. This can be explained by the site's normally low $\mathrm{NH}_{4}{ }^{+}$concentration, which could have been transformed to $\mathrm{NO}_{3}{ }^{-}$. (Pande 2005; Reddy and Delaune 2008).

\section{Contribution of hydrological conditions on the $\mathrm{NH}_{4}{ }^{+}$ and $\mathrm{NO}_{3}{ }^{-}$variation}

The two locations were chosen because the three primary floodplain hydrological zones, Valley Central, Valley Middle, and Valley Fringe, have distinct hydrology (Reddy and DeLaune 2008), which significantly affects N status. The Valley Central zone was submerged for the length of the experiment and so abandoned. The remaining two locations shared a high degree of hydrological similarity, as indicated by their redox potential.

Throughout the rice cropping period, both sites demonstrated reducing conditions for three weeks at the Middle site and two weeks at the Fringe site, followed by occasional variations between moderately reduced and reduced soil conditions between weeks 6 and 10, as illustrated in the Figures 11 and 12. Between weeks 12 and 16 , both sites' soils reverted to aerobic conditions. This close-in redox potential is critical in explaining the similarities between the two sites in root zone NH4+ and NO3- levels. Numerous results from $\mathrm{N}$ dynamics studies conducted over time demonstrate the effect that hydrological conditions can have on wetland $\mathrm{N}$ dynamics. $\mathrm{NO}_{3}{ }^{-}$removal has been measured in wetlands agricultural fields in the United States of America, New Zealand's Scotsman Valley, and Denmark's Rabis Bk (Brusch and Nilsson 1993). Devito et al. (1989) discovered that while there was no significant net retention of nitrogen inside five wetlands on the Canadian wetland, there was the transition of inorganic nitrogen to organic nitrogen, which influenced $\mathrm{NH}_{4}{ }^{+}$and $\mathrm{NO}_{3}{ }^{-}$dynamics under various hydrological conditions.

Additionally, Cai et al. (2002) observed a loss of $\mathrm{NH}_{4}{ }^{+}$ content in lowland wetland soils under various hydrological conditions. Despite this, Asante (2015) showed no significant association between $\mathrm{NO}_{3}{ }^{-}$status in wetland soils in Ghana's inland valleys under distinct hydrological zones. This is consistent with Yameogo's (2017) findings, who found that the $\mathrm{NO}_{3}{ }^{-}$level was not significantly different between treatments in an inland valley in the West African Savanna Zone with varying hydrological conditions.
As a result of these findings, the $\mathrm{NH}_{4}{ }^{+}$and $\mathrm{NO}_{3}{ }^{-}$ concentrations in the Valley Middle and Valley Fringe zones did not differ considerably. As a result, the presumed difference in $\mathrm{NH}_{4}{ }^{+}$and $\mathrm{NO}_{3}{ }^{-}$status between the two sites due to hydrologic changes cannot be validated. As a result, the null hypothesis is supported.

In conclusion, the pre-rice growing season observed three distinct periods of change in $\mathrm{NH} 4+$ content. The initial phase of increasing $\mathrm{NH}_{4}^{+}$content occurs between the first and sixth weeks of therapy, followed by a period of $\mathrm{NH}_{4}{ }^{+}$drop between the fifth and ninth weeks and an increase in $\mathrm{NH}_{4}{ }^{+}$level between the tenth and thirteenth seasons. The peak $\mathrm{NH}_{4}{ }^{+}$concentration in the first phase varied between treatments. Peak $\mathrm{NH}_{4}{ }^{+}$production was significantly increased $(\mathrm{P}=0.05)$ in both Middle Fringe sites in treatments with external $\mathrm{N}$ input (TR4, TR5, and TR6). Significant variations $(\mathrm{P}=0.05)$ in $\mathrm{NH}_{4}{ }^{+}$were also observed at the Middle site during the early stages of the fall in $\mathrm{N}$ (Week 6), with the following trend: TR6 $>$ TR5 $=$ TR4 $>$ TR3 $=$ TR2 $=$ TR1.

The initial $\mathrm{NH}_{4}{ }^{+}$concentration at the start of the rice cropping season varied significantly between treatments, with the highest values mainly occurring in treatments receiving external $\mathrm{N}$ input during the 2014/15 season. TR4 and TR5 were located at the Middle site, while TR4, TR5, and TR6 were located at the Fringe site. $\mathrm{NH}_{4}{ }^{+}$tended to decline constantly from week 1 to the start of the cropping season's end (week 16) for practically all treatments at the Middle site that lacked exogenous mineral N. At the Fringe site, the drop in $\mathrm{NH}_{4}{ }^{+}$followed a similar pattern between weeks 4 and 8 , then stabilized or increased somewhat regardless on the treatment.

During the pre-rice cropping season, the initial (beginning) $\mathrm{NO}_{3}{ }^{-}$content ranged from 0.001706 (TR2) to 0.002951 (TR6) $\mathrm{g} / \mathrm{kg}$ soil at the Middle site and from 0.0 to $0.0003604 \mathrm{~g} / \mathrm{kg}$ soil at the East site. $\mathrm{NO}_{3}{ }^{-}$content declined rapidly (within 1-2 weeks) at both sites, reaching the lowest values within 1-2 weeks. $\mathrm{NO}_{3}^{-}$the content was either nonexistent or extremely low in all treatments between weeks 2 and 3 (Middle) and weeks 2 and 6 (Fringe). The conclusion of the pre-season was marked by an increase in $\mathrm{NO}_{3}{ }^{-}$content (week 5-10 for the Middle site and week 7-10 for the Fringe site). The addition of urea at week 6 resulted in a rapid and transient increase in $\mathrm{NO}_{3}{ }^{-}$at the start of the booting stage at both sites.

\section{REFERENCES}

Asante M. 2015. Nitrogen dynamics in lowland rice cropping systems in inland valleys of Northern Ghana. J Plant Nutr Soil Sci 180 (1): 87 95. DOI: $10.1002 /$ jpln.201600209.

Audet J, Carl CH, Peter MA, Baattrup-Pedersen J, Johansen JR, Larsen SE, Kjaergaard C, Elsgaard L. 2014. Nitrous oxide fluxes in undisturbed riparian wetlands located in agricultural catchments: Emission, uptake, and controlling factors. Soil Biol Biochem 68: 291299. DOI: 10.1016/j.soilbio.2013.10.011.

Becker M, Ladha JK, Ali M. 1995. Green manure technology: Potential, usage, and limitations. A case study for lowland rice. In: Ladha JK, Peoples MB (eds). Management of Biological Nitrogen Fixation for the Development of More Productive and Sustainable Agricultural Systems. Developments in Plant and Soil Sciences. Springer, Amsterdam. DOI: 10.1007/978-94-011-0053-3_8. 
Becker M, Maskey SL, Pande KR, Shah SC, Shrestha SC. 2007. Effects of transition season management on soil $\mathrm{N}$ dynamics and system $\mathrm{N}$ balances in rice-wheat rotations of Nepal. Field Crops Res 103 (2): 98-108. DOI: 10.1016/j.fcr.2007.05.002.

Blake GR, Hartge KH. 1986. Bulk density. In: Klute A (eds). Methods of Soil Analysis Part 1. Physical and Mineralogical Methods, 2 Edition. Soil Science Society of America, Madison, USA. DOI: 10.2136/sssabookser5.1.2ed.

Brady NC, Weil RR. 1999. The Nature and Properties of Soils, $12^{\text {th }}$ Edition. Prentice-Hall, New Jersey.

Bremner JM, Mulvaney CS. 1982. Nitrogen-total. In: Page AL, Miller RH, Keeney DR (eds). Methods of Soil Analysis. Part 2. Chemical and Microbiological Properties. American Society of Agronomy, Soil Science Society of America, Madison, Wisconsin, USA.

Brusch W, Nilsson B. 1993. Nitrate transformation and water movement in a wetland area. Hydrobiology 251: 103-111. DOI: 10.1007/BF00007170.

Buresh RJ, Kamesh K, Reddy D, Chris VK. 2008. Nitrogen transformation in submerged soils. In: Scheper JS, Raun WR (eds). Agricultural System. James Currey, Oxford.

Cai GX, Chen DL, Ding H, Pacholski A, Fan XH, Zhu ZL. 2002. Nitrogen losses from fertilizers applied to maize, wheat, and rice in the North China Plain. Nutr Cycl Agroecosyst 63 (2): 187-195. DOI: 10.1023/A:1021198724250.

Carmona FP, Anghinoni I, Cao EG. 2012. Dynamics of ammonium and $\mathrm{pH}$ in the solution of soils with different salinity levels, growing irrigated rice. Revista Brasileira de Ciência do Solo 36 (2): 401 - 409. DOI: 10.1590/S0100-06832012000200009.

Corstanje R, Reddy KR. 2004. Response of biogeochemical indicators to a drawdown and subsequent reflood. J Environ Qual 33 (6): 2357-2366. DOI: $10.2134 /$ jeq2004.2357.

Deenik J. 2006. Nitrogen mineralization potential in important agricultural soils of Hawaii. Soil Crop Manag 15:1-15.

Devito KJ, Dillon PJ, Lazerte BD. 1989. Phosphorus and nitrogen retention in five Precambrian shield watersheds. Biogeochemistry 8: 185-204. DOI: 10.1007/BF00002888.

Dharmakeerthi RS, Thenabadu MW. 1996. Urease activities in soils: A review. J Nat Conserv Sri Lanka 24 (3): 159-195. DOI: 10.4038/jnsfsr.v24i3.5548.

Eder A, Bloschl G, Feichtinger F, Herndl M, Klammler G, Hosch J, Erhart E, Strauss P. 2015. Indirect nitrogen losses of managed soils contributing to greenhouse emissions of agricultural areas in Austria: Results from lysimeter studies. Nutr Cycl Agroecosyst 101 (3): 351364. DOI: $10.1007 / \mathrm{s} 10705-015-9682-9$.

Gee WG, Bauder JM. 1986. Particle size analysis. In: Klute A (eds) Methods of Soil Analysis Part 1. Physical \& Mineralogical Methods. American Society of Agronomy, Madison, USA.

Ghosh BC, Bhat R. 1998. Environmental hazards of nitrogen loading in wetland rice fields. Environ Pollut 102 (1): 123-126. DOI 10.1016/S0269-7491(98)80024-9.

Gichuki NN, Macharia JM. 2006. Socio-economic dimensions of conservation of wetlands in African drylands: A case study of River Ewaso Ngiro basin in southern Kenya. Oceandocs 2: 364-369.

Gilmour CM, Broadbent FE, Beck SM. 1977. Recycling of carbon and nitrogen through land disposal of various wastes. In: Elliot LF, Steven CSE (eds). Soil for management for organic wastes and waste water. American Society of Agronomy, Madison, USA.

Houba VJG, Novozamsky I, Huybregts AWM, van der Lee JJ. 1986. Comparison of soil extractions by $0.01 \mathrm{M} \mathrm{CaCl}_{2}$, by EUF and by some conventional extraction procedures. Plant Soil 96 (3): 433 - 437. DOI: 10.1007/BF02375149.

Inamura T, Mukai Y, Maruyama A, Ikenaga S, Li G, Bu X, Xiang Y, Qin D, Takahisa A. 2009. Effects of nitrogen mineralization on paddy yield under low input conditions in irrigated rice-based multiple cropping with intensive cropping of vegetables in Southwest China. Plant Soil 315 (1): 195-209. DOI: 10.1007/s11104-008-9744-8.

Jones CA, Koenig RT, Ellsworth JW, Brown BD, Jackson GD. 2007. Management of Urea Fertilizer to Minimize Volatilization. Montana State University, Montana, USA.

Kanyeka E, Kamala R, Kasuga R. 2007. Improved Agricultural Technologies Recommended in Tanzania. Department of Research and Training, Ministry of Agriculture Food Security and Cooperatives, Dar es Salaam, Tanzania.

Kato F. 2007. Development of major rice cultivation is in the Kilombero Valley, Tanzania. Afr Stud Monogr 36: 3-18.
Kimetu JM, Mugendi DN, Bationo A, Palm CA, Mutuo PK, Kihara J, Nandwa S, Giller K. 2006. Partial balance of nitrogen in a maize cropping system in humic nitisol of Central Kenya. In: Bationo A, Waswa B, Kihara J, Kimetu J (eds). Advances in Integrated Soil Fertility Management in sub-Saharan Africa: Challenges and Opportunities. Springer, Dordrecht. DOI: 10.1007/978-1-4020-57601_49.

Kunamneni A, Poluri E, Davuluri SP. 2003. Purification and partial characterization of thermostable serine alkaline protease from a newly isolated Bacillus subtilis pe 11. Pharm Sci Technol 4 (4): 440 - 448. DOI: $10.1208 / \mathrm{pt} 040456$

Linn ID, Doran JW. 1984. Effect of water-filled pore space on carbon dioxide and nitrous oxide production in tilled and non-tilled soils. Soil Sci Soc Am J 48 (6): 1267-1271. DOI: 10.2136/sssaj1984.03615995004800060013x.

Loomis RS, Connor DJ. 1992. Crop Ecology: Productivity and Management in Agricultural Systems. Cambridge University Press, Cambridge, UK. DOI: 10.1017/CBO9781139170161.

Lou YL, Xu MG, Wang W, Sun XL, Zhao K. 2011. Return rate of straw residue affects soil organic $\mathrm{C}$ sequestration by chemical fertilization. Soil Tillage Res 113 (1): 70-73. DOI: 10.1016/j.still.2011.01.007.

Marschner H. 2008. Mineral Nutrition of Higher Plants. Academic Press, London, UK.

McLean EO. 1982. Soil pH and lime requirement. In: Page AL (eds). Methods of Soil Analysis Part 2. Chemical and Microbiological Properties. American Society of Agronomy, Madison, USA.

Meng F, Olesen JE, Sun X, Wu W. 2014. Inorganic nitrogen leaching from organic and conventional rice production on a newly claimed calciustoll in Central Asia. Plos One 9 (5): 75-81. DOI: 10.1371/journal.pone.0098138.

Ministry of Natural Resources and Tourism (MNRT). 2004a. The Development and Implementation of an Integrated Management Plan of Kilombero Valley Flood Plain Ramsar Site Identification Report. Dar es Salaam, Tanzania.

Ministry of Natural Resources and Tourism (MNRT). 2004b. An Issue Paper for the Formulation of the National Wetlands Strategy. Dar es Salaam, Tanzania.

Moata MRS, Takalapeta AM. 2021. Short Communication: Agroforestry as sustainable agroecosystem in terrestrial semi-arid region, Indonesia: Evidence from soil organic carbon. Intl J Trop Drylands 5 (1): 1-4. DOI: 10.13057/tropdrylands/t050101.

Muhammad AR, Asghar A, Muhammad AM, Mumtaz H. 2010. Effect of fertilizer levels and plant densities on yield and protein contents of autumn planted maize. Pak J Agric Sci 47 (3): 201 - 208.

Nascente AS, Crusciol CA, Cobucci T. 2009. Ammonium and nitrate in soil and upland rice yield as affected by cover crops and their desiccation time. Crop Sci 47 (12): 1699-1706. DOI: 10.1590/S0100204X2012001200004.

Nelson DW, Sommers LE. 1982. Total carbon, organic carbon, and organic matter. In: Page AL (eds). Methods of Soil Analysis Part 2. Chemical and Microbiological Properties. American Society of Agronomy, Madison, USA.

Ngwene B, Gabriel E, George E. 2013. Influence of different mineral nitrogen sources $\left(\mathrm{NO}_{3}{ }^{-} \mathrm{N}\right.$ vs. $\left.\mathrm{NH}{ }^{+}-\mathrm{N}\right)$ on Arbuscular mycorrhiza development and $\mathrm{N}$ transfer in a Glomus intraradices-Cowpea symbiosis. Mycorrhiza 23 (2): 107-117. DOI: 10.1007/s00572-0120453-z.

Njoroge KS, Mugendi DN, Vanlauwe B. 2018. Effect of fertilizer-N and organic resource management on soil aggregates formation and carbon cycling in the central highlands of Kenya. Asian J Agric 2 (1): 25-37. DOI: 10.13057/asianjagric/g020105.

Nziguheba G, Merckx R, Palm CA. 2005. Carbon and nitrogen dynamics in phosphorus-deficient soil amended with organic residues and fertilizers in western Kenya. Biol Fertil Soils 41 (4): 240-248. DOI: 10.1007/s00374-005-0832-0.

Olk DC, Cassman KG, Randall EW, Kinchesh P, Sanger LJ, Anders JM. 1996. Changes in chemical properties of organic matter with intensified rice cropping in tropical lowland soils. Eur J Soil Sci 47 (3): 293-303. DOI: 10.1111/j.1365-2389.1996.tb01403.x.

Olsen SR, Sommers LE. 1982. Phosphorus. In: Page AL (eds). Methods of Soil Analysis Part 2. Chemical and Microbiological Properties. American Society of Agronomy, Madison, USA.

Pal D, Broadbent FE. 1975. Influence of moisture on rice straw decomposition in soil. Soil Sci Soc Am J 39 (1): 59-63. DOI: 10.2136/sssaj1975.03615995003900010018x. 
Pande KR. 2005. Managing Seasonal Soil Nitrogen Dynamics in Rice Wheat Rotation System of Nepal. [Dissertation]. Universität Bonn, Germany.

Payne RW. 2009. "Genstat". Wiley interdisciplinary reviews: Computational statistics. 1 (2): 255-258. DOI: 10.1002/wics.32.

Pereira NS, Soares I, de Miranda FR. 2016. Decomposition and nutrient release of leguminous green manure species in the Jaguaribe-Apod region, Ceará, Brazil. Ciência Rural, Santa Maria, 46 (6): 970-975. DOI: $10.1590 / 0103-8478$ cr20140468.

Pezeshki SR, DeLaune RD. 2012. Soil oxidation-reduction in wetlands and its impact on plant functioning. Biology 1 (2): 196-221. DOI: 10.3390/biology1020196.

Reardon J, Foreman JA, Searcy RL. 1966. New reactants for the colorimetric determination of ammonia. Clinica Chimica Acta 14 (3): 403-405. DOI: 10.1016/0009-8981(66)90120-3.

Reddy KR, DeLaune R, Craft CB. 2010. Nutrients in wetlands: Implications to water quality under changing climatic conditions. Final Report submitted to U.S. Environmental Protection Agency, USA.

Reddy KR, Delaune RD. 2008. Biogeochemistry of Wetlands. Taylor and Francis Group, New York. DOI: 10.1201/9780203491454.

Reddy KR, Patrick Jr WH. 1975. Effect of alternate aerobic and anaerobic conditions on redox potential, organic matter decomposition, and nitrogen loss in a flooded soil. Soil Biol Biochem 7 (2): 87-94. DOI 10.1016/0038-0717(75)90004-8.

Rostaminia M, Mahmoodi S, Gol H, Sefidi T, Pazira E, Kafaee SB. 2011. Study of reduction-oxidation potential and chemical characteristics of a paddy field during rice growing season. Res J Appl Sci 11 (6) 1004-1011. DOI: 10.3923/jas.2011.1004.1011.

Sahrawat KL. 2010. Nitrogen mineralization in lowland rice soils: The role of organic matter quantity and quality. Archiv Agronom Soil Sci 56 (3): 337-353. DOI: 10.1080/03650340903093158.

Samora M, Andrew T, Stein RM. 2013. Invasion of the cosmopolitan species Echinochloa colona into herbaceous vegetation of a tropical wetland system. Ecology 29 (5): 969-979. DOI: 10.1007/s11284-014 1185-7.

Smil V. 2000. Cycles of Life. Scientific American Library, New York.

Smith AS. 2010. Nitrogen and Phosphorus Cycling in Mid-Western Agricultural Wetlands in Response to Altered Hydrologic Regimes. [Dissertation] Indiana University, India.

Sugihara S, Funakawa S, Kilasara M, Kosak T. 2010a. Effect of land management and soil texture on seasonal variations in soil microbial biomass in dry tropical agro ecosystems in Tanzania. Appl Soil Ecol 44 (1): 80-88. DOI: 10.1016/j.apsoil.2009.10.003.

Sugihara S, Funakawa S, Kilasara M, Kosak T. 2010b. Dynamics of microbial biomass nitrogen uptake during the crop cropland in
Tanzania nitrogen in relation growth period in a to plant dry tropical. Soil Sci Plant Nutr 56: 105-114. DOI: 10.1111/j.17470765.2009.00428.x.

Suryantini. 2016. Effect of phosphorus, organic and biological fertilizer on yield of mungbean (Vigna radiata) under two cropping patterns. Nusantara Biosci 8 (2): 273-277. DOI: 10.13057/nusbiosci/n080222.

Susanto D, Kusuma R, Amirta R. 2018. Nutrient distribution on soil and aboveground biomass of Macaranga gigantea five years after planting. Asian J For 2 (1): 12-19. DOI: 10.13057/asianjfor/r020102.

Swinehart BA, Warren WB. 1953. The spectrophotometry determination of nitrate ion in 75\% sulfuric acid. Proc Indiana Acad Sci 63: 13031309 .

Toure A, Becker M, Johnson DE, Kone B, Kossou DK, Kiepe P. 2009. Response of lowland rice to agronomic management under different hydrological regimes in an inland valley of Ivory Coast. Field Crop Res 114 (2): 304-310. DOI: 10.1016/j.fcr.2009.08.015.

Vorenhout M, van der Geest HG, van Marum D, Eijsackers H. 2004. Automated and continuous redox potential measurements in soil. J Environ Qual 33 (4): 1562-1567. DOI: 10.2134/jeq2004.1562.

Walker JP, Willgoose GR, Kalma JD. 2004. In situ measurement of soil moisture: a comparison of techniques. J Hydrol 293 (1-4): 85-99. DOI: $10.1016 /$ j.jhydrol.2004.01.008.

Wang MY, Siddiqi MY, Ruth TJ, Anthony DM. 1993. Ammonium uptake by rice roots II. Kinetics of $13 \mathrm{NH}_{4}{ }^{+}$Influx across the Plasmalemma. Plant Physiol 103 (4): 1259-1267. DOI: 10.1104/pp.103.4.1259.

Wang WJ, Baldock JA, Dalal RC, Moody PW. 2004. Decomposition dynamics of plant residues in relation to nitrogen availability and biochemistry determined by NMR and wet-chemical analysis. Soil Biol Biochem $36 \quad$ (12): 2045-2058. DOI: 10.1016/j.soilbio.2004.05.023.

Yadvinder-Singh CS, Bijay-Singh C, Timsina J. 2005. Crop residue management for nutrient cycling and improving soil productivity in rice- based cropping systems in the tropics. Adv Agronom 85: 269407. DOI: 10.1016/S0065-2113(04)85006-5.

Yameogo PL. 2017. Managing Seasonal Soil Nitrogen Dynamics in Inland Valleys of the West African Savanna Zone. [Dissertation]. Universität Bonn, Germany.

Yeasmin S, Mominul AKM, Aminul IAK. 2012. Nitrogen fractionation and its mineralization in paddy soils: a review. J Agric Technol 8 (3): 775-793.

Zaman M, Di H, Cameron KC, Frampton CM. 1999. Gross nitrogen mineralization and nitrification rates and their relationships to enzyme activities and the soil microbial biomass in soils treated with dairy shed effluent and ammonium fertilizer at different water potentials. Biol Fertil Soils 29 (2): 178-186. DOI: 10.1007/s003740050542. 